\title{
Nitrous oxide emissions from a commercial cornfield (Zea mays) measured using the eddy covariance technique
}

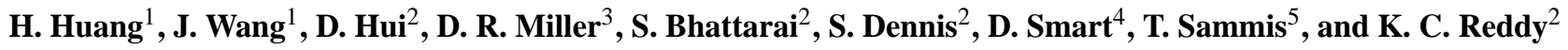 \\ ${ }^{1}$ Climate and Atmospheric Science Section, Illinois State Water Survey, Prairie Research Institute, \\ University of Illinois at Urbana-Champaign, Champaign, IL 61802, USA \\ ${ }^{2}$ College of Agriculture, Human and Natural Sciences, Tennessee State University, Nashville, TN 37209, USA \\ ${ }^{3}$ Department of Natural Resources and Environment, University of Connecticut, Storrs, CT 06269, USA \\ ${ }^{4}$ Department of Viticulture and Enology, University of California, Davis, CA 95616, USA \\ ${ }^{5}$ Department of Plant and Environmental Science, New Mexico State University, Las Cruces, NM 88003, USA \\ Correspondence to: J. Wang (wangjim@illinois.edu)
}

Received: 17 May 2014 - Published in Atmos. Chem. Phys. Discuss.: 8 August 2014

Revised: 27 October 2014 - Accepted: 10 November 2014 - Published: 8 December 2014

\begin{abstract}
Increases in observed atmospheric concentrations of the long-lived greenhouse gas nitrous oxide $\left(\mathrm{N}_{2} \mathrm{O}\right)$ have been well documented. However, information on eventrelated instantaneous emissions during fertilizer applications is lacking. With the development of fast-response $\mathrm{N}_{2} \mathrm{O}$ analyzers, the eddy covariance (EC) technique can be used to gather instantaneous measurements of $\mathrm{N}_{2} \mathrm{O}$ concentrations to quantify the exchange of nitrogen between the soil and atmosphere. The objectives of this study were to evaluate the performance of a new EC system, to measure the $\mathrm{N}_{2} \mathrm{O}$ flux with the system, and finally to examine relationships of the $\mathrm{N}_{2} \mathrm{O}$ flux with soil temperature, soil moisture, precipitation, and fertilization events. An EC system was assembled with a sonic anemometer and a fast-response $\mathrm{N}_{2} \mathrm{O}$ analyzer (quantum cascade laser spectrometer) and applied in a cornfield in Nolensville, Tennessee during the 2012 corn growing season (4 April-8 August). Fertilizer amounts totaling $217 \mathrm{~kg} \mathrm{Nha}^{-1}$ were applied to the experimental site. Results showed that this $\mathrm{N}_{2} \mathrm{O}$ EC system provided reliable $\mathrm{N}_{2} \mathrm{O}$ flux measurements. The cumulative emitted $\mathrm{N}_{2} \mathrm{O}$ amount for the entire growing season was $6.87 \mathrm{~kg} \mathrm{~N}_{2} \mathrm{O}-\mathrm{N} \mathrm{ha}^{-1}$. Seasonal fluxes were highly dependent on soil moisture rather than soil temperature. This study was one of the few experiments that continuously measured instantaneous, high-frequency $\mathrm{N}_{2} \mathrm{O}$ emissions in crop fields over a growing season of more than 100 days.
\end{abstract}

\section{Introduction}

As the largest corn producer in the world, the United States produces about one-third of the world's corn crop (about 84 million ha in 2011) (http://www.epa.gov/agriculture/ag101/ cropmajor.html). Corn is a nitrogen (N)-intensive crop. Every year, large amounts of $\mathrm{N}$ are applied to cornfields, but its efficiency is low (30-59\%) (Halvorson et al., 2005). A large proportion of applied $\mathrm{N}$ can leach into groundwater (e.g., $\mathrm{NO}_{3}^{-}$) and/or be emitted into the atmosphere (e.g., nitrous oxide, $\mathrm{N}_{2} \mathrm{O}$; nitric dioxide, $\mathrm{NO}$; or nitrogen dioxide, $\mathrm{NO}_{2}$ ).

$\mathrm{N}_{2} \mathrm{O}$ is one of the longest-lived greenhouse gases and has an estimated radiative forcing of $0.15 \mathrm{~W} \mathrm{~m}^{-2}$, compared to carbon dioxide $\left(\mathrm{CO}_{2}\right)$ at $2.43 \mathrm{~W} \mathrm{~m}^{-2}$ and methane $\left(\mathrm{CH}_{4}\right)$ at $0.48 \mathrm{~W} \mathrm{~m}^{-2}$ (Forster et al., 2007). In addition to its contribution to global warming, $\mathrm{N}_{2} \mathrm{O}$ also plays an important role in stratospheric ozone depletion through $\mathrm{O}$ (1-D) oxidation (Ravishankara et al., 2009). The volume concentration of $\mathrm{N}_{2} \mathrm{O}$ in the atmosphere has increased from 273 parts per billion dry air mole fraction (ppbv) in 1950 to 319 ppbv in 2005 (Forster et al., 2007). The major source of anthropogenic $\mathrm{N}_{2} \mathrm{O}$ in the atmosphere is believed to be $\mathrm{N}$ fertilization, accounting for up to $80 \%$ of anthropogenic $\mathrm{N}_{2} \mathrm{O}$ emissions (Kroeze et al., 1999; Mosier et al., 1998). $\mathrm{N}_{2} \mathrm{O}$ emitted from soil is produced by bacterial processes, mainly through nitrification and denitrification (Davidson and Swank 1986). These processes may be affected by several factors, including the percentage of water-filled pore spaces in soil (WFPS) 
(Dobbie and Smith 2003; Davidson 1991), mineral N concentrations in the soil (Ma et al., 2010; Bouwman et al., 2002; Bouwman 1996), crop type, soil type, soil moisture, air/soil temperature, and oxygen supply within the soil strata. Therefore, $\mathrm{N}_{2} \mathrm{O}$ emissions are typically highly variable both in time and space and are difficult to quantify.

Significant efforts have been invested in developing reliable tools for measuring instantaneous $\mathrm{N}_{2} \mathrm{O}$ emissions from the soil into the atmosphere. The two major measurement methods currently available for $\mathrm{N}_{2} \mathrm{O}$ fluxes are the chamber method and the eddy covariance (EC) method (Denmead 2008; Molodovskaya et al., 2011). The chambers, either closed (static) or open (dynamic flow), are the traditional tools that have been used in different land management systems (farmland, forest, and grassland) (Tao et al., 2013; Liu et al., 2012; Arnolda et al., 2005; Klemedtsson et al., 1996). The chamber method is simple in concept and operation, as well as low in cost. However, several limitations may affect the data quality, such as small area coverage $\left(\leq 1 \mathrm{~m}^{2}\right.$, called the footprint), disturbance of the soil environment, and low sampling frequency (Molodovskaya et al., 2011; Denmead 2008). The EC method calculates the spatial-averaged flux from a larger "field scale footprint" $\left(10 \mathrm{~m}^{2}-1 \mathrm{~km}^{2}\right)$ (Denmead 2008). Unlike the chamber method, the EC method does not disturb the soil and crop ecosystem and provides a continuous and real-time flux measurement.

The EC method is based on the Reynolds decomposition theory that a turbulent variable $(x)$ can be represented by a time-averaged component $(\bar{x})$ and a fluctuation component $\left(x^{\prime}\right)$ (e.g., Famulari et al., 2010; Kaimal and Finnigan 1994; Stull 1988):

$x=\bar{x}+x^{\prime}$.

In the EC method, the vertical flux of a gas is expressed as the covariance between the vertical wind velocity and gas concentration:

$J=\overline{\omega^{\prime} c^{\prime}}$,

where $J$ is the gas vertical flux, $\omega^{\prime}$ and $c^{\prime}$ are the deviations of vertical wind velocity $(\omega)$ and gas concentration $(c)$, and the overbar represents a time average. The EC method requires rapid, simultaneous (or near-simultaneous) measurements of gas concentration and wind velocity at the same point in space. With the developments of fast-response $\mathrm{N}_{2} \mathrm{O}$ analyzers in recent years, the EC method has become more common (Jones et al., 2011; Mammarella et al., 2010; Eugster et al., 2007; Pihlatie et al., 2005; Di Marco et al., 2004; Edwards et al., 2003). In this project, an EC system for $\mathrm{N}_{2} \mathrm{O}$ measurement was assembled in a commercial cornfield in Nolensville, Tennessee with a newly available fast-response $\mathrm{N}_{2} \mathrm{O}$ analyzer: a quantum cascade laser (QCL) spectrometer (model CW-QC-TILDAS-76-CS, Aerodyne Research Inc., Billerica MA).

The objectives of this study were to evaluate the performance of the new $\mathrm{N}_{2} \mathrm{O}$ spectrometer in the $\mathrm{EC}$ system, to

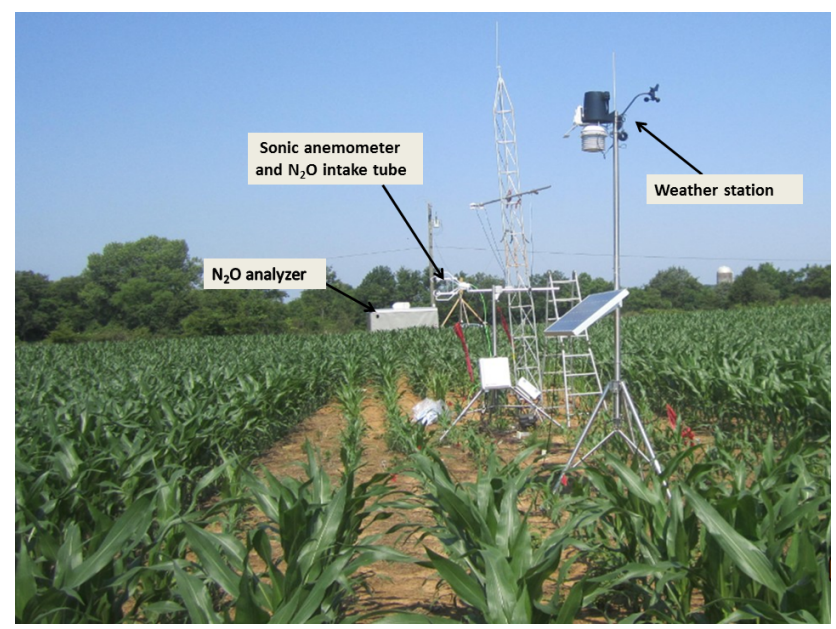

Figure 1. Photo of the experimental site, Williamson County (Nolensville, TN).

measure the $\mathrm{N}_{2} \mathrm{O}$ flux with the system, and finally to examine relationships between the $\mathrm{N}_{2} \mathrm{O}$ flux and soil temperature, soil moisture, precipitation, and fertilization events.

\section{Materials and methods}

\subsection{Site description}

The experimental site was located in a commercial cornfield in Nolensville, Tennessee, $35 \mathrm{~km}$ south of Nashville (Fig. 1). The field was $300 \mathrm{~m}$ (east-west) by $500 \mathrm{~m}$ (south-north) with a $2 \%$ slope facing west. The soil type was Talbott silty clay loam (fine, mixed, semiactive thermic Typic Hapludalfs: $32.5 \%$ sand, $53.8 \%$ silt, $13.8 \%$ clay) (http://websoilsurvey.nrcs.usda.gov/app/ WebSoilSurvey.aspx). Soybeans were planted in the previous year's rotation. Corn seeds (Roundup Ready BT Hybrid Corn, P1412 HR, Pioneer Hi-Bred International Inc., Johnston, IA) were sown on 9 April 2012. Measurements were continuous from 4 April to 8 August 2012, covering the entire corn-growing season.

The agricultural practice was no-till. A weather station (Vantage PRO2 Plus, Davis Instruments, Vernon Hills, IL) was used to record $30 \mathrm{~min}$ precipitation, temperature, pressure, wind speed and direction, relative humidity $(\mathrm{RH})$, and solar radiation. The prevailing wind direction was from the southwest during the growing season.

\subsection{The EC instruments}

A sonic anemometer (CSAT3-A, Campbell Sci, Logan, UT) located in the middle of the field measured three-dimensional wind velocities and virtual air temperatures at a sampling rate of $10 \mathrm{~Hz}$. It was positioned $1.3 \mathrm{~m}$ above the canopy and was raised as the corn plants grew taller. $\mathrm{N}_{2} \mathrm{O}$ concentrations 
were measured by a QCL spectrometer. The $\mathrm{N}_{2} \mathrm{O}$ analyzer was housed in a trailer where a stable working temperature (293-303 K) was maintained. The pressure of the spectrometer sample cell was $4 \mathrm{kpa}$ (30 Torr). The laser was operated at a wave number of $2193 \mathrm{~cm}^{-1}$.

The $\mathrm{N}_{2} \mathrm{O}$ analyzer was located $50 \mathrm{~m}$ from the sonic anemometer. Following the specifications of Eugster et al. (2007), a sampling Teflon tube $(6 \mathrm{~mm}$ inner diameter, $50 \mathrm{~m}$ length) was used to sample the air at the EC sonic anemometer location in the middle of the field and was connected to the $\mathrm{N}_{2} \mathrm{O}$ analyzer. The tube intake was $20 \mathrm{~cm}$ from the sonic anemometer. Sample air was drawn into the tube intake at a rate of STD $\mathrm{Lmin}^{-1}$. The analyzer provided $10 \mathrm{~Hz}$ measurements of $\mathrm{N}_{2} \mathrm{O}$ and water vapor $\left(\mathrm{H}_{2} \mathrm{O}\right)$ concentrations. The analyzer automatically corrected the $\mathrm{H}_{2} \mathrm{O}$ effects on $\mathrm{N}_{2} \mathrm{O}$ measurements (WPL and cross-sensitivity of $\mathrm{H}_{2} \mathrm{O}$ on $\mathrm{N}_{2} \mathrm{O}$ ) in real time (Nelson, 2002). A Campbell Scientific CR3000 data logger was used to record all the data collected at $10 \mathrm{~Hz}$. The EC measurement footprint ranged from 25 to $90 \mathrm{~m}$ upwind and was calculated using the software EddyPro (version 3.0, LI-COR Biosciences, Lincoln, NE). Soil moisture and soil temperatures were measured with a water content reflectometer (CS616) and an averaging soil thermocouple probe (TCAV, Campbell Sci, Logan, UT), which were buried vertically at a depth of $0-10 \mathrm{~cm}$ underground. The mineral $\mathrm{NO}_{3}^{-}$and $\mathrm{NH}_{4}^{+}$concentrations in the top $10 \mathrm{~cm}$ of soil were measured using a Lachat flow injection autoanalyzer (Loveland, $\mathrm{CO}$ ), which mixes the sample (liquid state) homogeneously with reagents to form a concentration gradient that yields analysis results.

\section{$2.3 \quad \mathrm{~N}_{2} \mathrm{O}$ flux calculation and data corrections}

The EddyPro version 3.0 was used to process and correct the $\mathrm{N}_{2} \mathrm{O}$ flux. EC fluxes were calculated as the covariance of the vertical wind velocity and $\mathrm{N}_{2} \mathrm{O}$ concentration over an averaging period:

$J_{\mathrm{N}_{2} \mathrm{O}}=\overline{\omega^{\prime} c_{\mathrm{N}_{2} \mathrm{O}}^{\prime}} \times \frac{\rho_{\mathrm{a}}}{M_{\mathrm{a}}} \times 3600 \times 28 \times 10^{-3}$,

where $J_{\mathrm{N}_{2} \mathrm{O}}$ is the $\mathrm{N}_{2} \mathrm{O}$ flux $\left(\mu \mathrm{g} \mathrm{N} \mathrm{N}_{2} \mathrm{O}-\mathrm{Nm}^{-2} \mathrm{~h}^{-1}\right), c_{\mathrm{N}_{2} \mathrm{O}}$ is the $\mathrm{N}_{2} \mathrm{O}$ concentration in air (ppbv), the component prime (') indicates a deviation from the mean, the overbar denotes a time average, $\rho_{\mathrm{a}}$ is the density of air $\left(\mathrm{kg} \mathrm{m}^{-3}\right), M_{\mathrm{a}}$ is the molar mass of air $\left(0.028965 \mathrm{~kg} \mathrm{~mol}^{-1}\right), 3600$ represents $3600 \mathrm{~s}$ per hour, and 28 is the molar mass of two $\mathrm{N}$ atoms in $\mathrm{N}_{2} \mathrm{O}$ $\left(\mathrm{g} \mathrm{mole}^{-1}\right)$.

The averaging period to determine eddy fluxes must be sufficient to adequately sample all the motions that contribute to the fluxes, but an overly long averaging period might affect measurements with irrelevant signals. According to Moncrieff et al. (2004), an averaging period of 30 to $60 \mathrm{~min}$ is appropriate for gas flux calculations. In this study, a commonly used averaging period of $30 \mathrm{~min}$ was chosen (Mammarella et al., 2010; Eugster et al., 2007; Aubinet et al., 2000).
EC measurements need several corrections before and after performing a flux calculation. Data spikes can be caused by random electronic spikes in the measuring or recording systems. The de-spike procedure was applied to the raw data $(10 \mathrm{~Hz})$ before the calculation of flux. The spike detection and removal method used in this study was similar to that of Vickers and Mahrt (1997). A spike was identified as up to three consecutive outliers with respect to a plausible range within a certain time range, and the spike was replaced with the linear interpolation between adjacent data points. The rationale is that if more consecutive values are found to exceed the plausibility threshold, they might be a sign of an unusual yet physical trend (not an outlier). The threshold was set to 3 to 8 times the standard deviation for a given averaging period ( 3 times for wind velocity and air temperature and 8 times for $\mathrm{N}_{2} \mathrm{O}$ concentrations; these parameters represent the default values in EddyPro).

The vertical axis of the sonic anemometer was not always aligned with the local normal to the surface. Therefore, there could be cross-contamination among components of the flux divergence. In order to avoid cross-contamination, an axis rotation was necessary. The EddyPro used a double rotation scheme, in which the $u$-component was aligned with a local streamline for each $30 \mathrm{~min}$ interval, and the $v$-component and $\omega$-component were forced to be zero on average.

The physical separation of the sonic anemometer and the $\mathrm{N}_{2} \mathrm{O}$ analyzer caused a time lag $(\tau)$ between the sonic data and $\mathrm{N}_{2} \mathrm{O}$ data. Compensation for $\tau$ before the covariance calculation is required in the EC technique. In this study, the $\tau$ for each $30 \mathrm{~min}$ averaging period was obtained by searching for the maximum cross covariance between sonic variables and analyzer measurements.

All EC systems applied to trace gas measurements tend to underestimate the true atmospheric fluxes; this is due to the physical limitations of the instruments, which cause flux losses at high (e.g., damping effects from long intake tube) and low frequencies. The commonly used methods of addressing spectral attenuation have been described (e.g., Ferrara et al., 2012, and Moncrieff et al., 2004). The EddyPro software program provides several options for spectral correction. In this study, at the low frequency range the analytic correction proposed by Moncrieff et al. (2004) was used, and at the high frequency range the spectral loss was corrected following Ibrom et al. (2007) and Horst and Lenschow (2009).

The frequency loss ratio $\left(\frac{\Delta \varnothing}{\varnothing}\right)$ was calculated as

$$
\frac{\Delta \varnothing}{\varnothing}=1-\frac{\int_{0}^{+\infty} \mathrm{CO}_{M} \mathrm{~d} f}{\int_{0}^{+\infty} \mathrm{CO}_{T} \mathrm{~d} f},
$$


where the $\mathrm{CO}_{T}$ is the theoretical $\mathrm{N}_{2} \mathrm{O}$ flux cospectrum following Kaimal et al. (1972), $\mathrm{CO}_{M}$ is the $\mathrm{N}_{2} \mathrm{O}$ flux cospectra from the measured data, and $f$ is the spectral frequency.

The EddyPro software outputs a frequency correction factor for $\mathrm{N}_{2} \mathrm{O}\left(\mathrm{N}_{2} \mathrm{O}-\mathrm{cf}\right)$ as the ratio of the frequencycorrected flux divided by the flux before the frequency correction. Therefore the frequency correction ratio by EddyPro $\left(\frac{\Delta \varnothing}{\varnothing}(\mathrm{EP})\right.$ is

$$
\frac{\Delta \varnothing}{\varnothing}(\mathrm{EP})=1-\frac{1}{\mathrm{~N}_{2} \mathrm{O}-\mathrm{cf}} \text {. }
$$

\subsection{Data for weak turbulence and precipitation conditions}

It has been found that under weak wind conditions with no surface heating, turbulence may not develop. Friction velocity $\left(u^{*}\right)$ was used to measure the turbulent state of the atmosphere:

$u^{*}=\left(\overline{\omega^{\prime} u^{\prime 2}}+\overline{\omega^{\prime} v^{\prime 2}}\right)^{\frac{1}{4}}$,

where $u^{\prime}$ and $v^{\prime}$ are the fluctuations in horizontal downwind and crosswind components.

The determination of an adequate $u^{*}$ threshold for sufficient turbulent mixing was crucial. The common method to determine the $u^{*}$ threshold is to examine the scatter plot of nighttime flux versus $u^{*}$; the threshold is located at the point at which flux begins to level off as $u^{*}$ increases (Gu et al., 2005). There are also many statistic-based algorithms used to determine $u^{*}$ thresholds (Papale et al., 2006; Gu et al., 2005; Saleska et al., 2003). Mammarella (2010) summarizes the appropriate range of the $u^{*}$ threshold as 0.1 for grassland to 0.3 for forest. In this study we used 0.2 as the threshold for the cornfield. A $u^{*}$ threshold value $\left(0.15 \mathrm{~m} \mathrm{~s}^{-1}\right)$ was obtained using the method in Barr et al., 2012. That value was similar to and slightly smaller than our threshold value of $0.2 \mathrm{~m} \mathrm{~s}^{-1}$. Therefore, our data processing using $0.2 \mathrm{~m} \mathrm{~s}^{-1}$ threshold value was conservative and warranted the exclusion of all the low-turbulence data and even some data just around the low- to normal-turbulence transition zone $\left(u^{*}\right.$ from 0.15 to $0.2 \mathrm{~m} \mathrm{~s}^{-1}$ ). During precipitation conditions, the sonic anemometer sensor heads could be wet, causing errors in the instantaneous measurements. Therefore in this study the $\mathrm{N}_{2} \mathrm{O}$ flux data were excluded in low turbulence, $u^{*}<0.2 \mathrm{~m} \mathrm{~s}^{-1}$, and during rainfall.

\subsection{Measurement periods}

As noted above, continuous measurements were carried out from 4 April to 8 August 2012. The corn was harvested one week after the study period ended. On 8 August, the moisture content of the kernels was less than $25 \%$; therefore the study period covered the entire growing season. Prior to planting and before the EC measurements were initiated, chicken litter $\left(99 \mathrm{~kg} \mathrm{Nha}^{-1}\right)$ was applied to the field on 10 March.

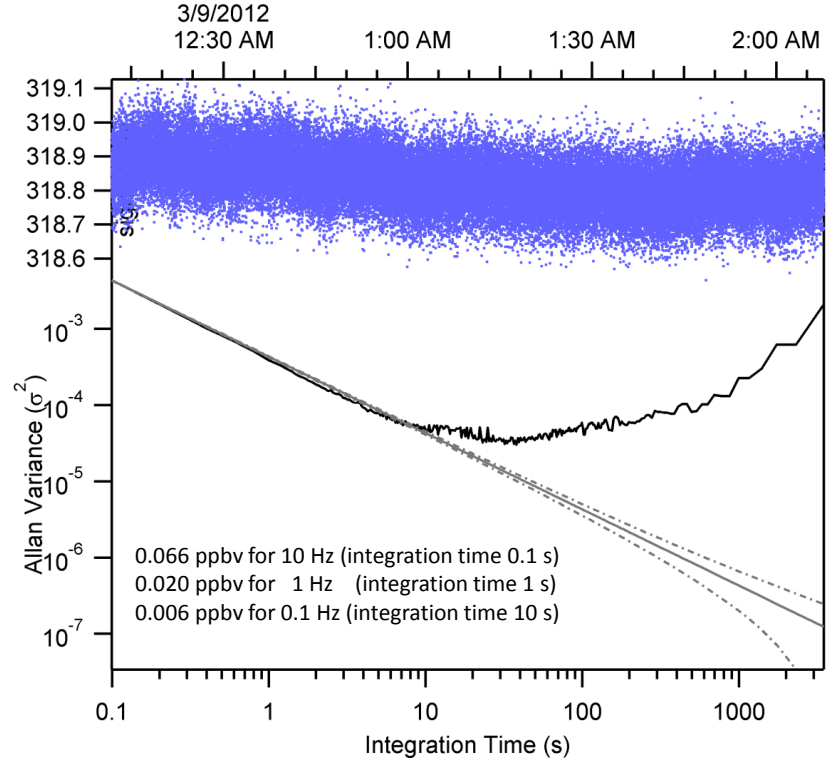

Figure 2. Time series of measured $\mathrm{N}_{2} \mathrm{O}$ concentrations (blue dots, ppbv, $10 \mathrm{~Hz}$ ) under field conditions and the associated Allan variance. Downward-sloping straight line shows the theoretical behavior of white noise (with a slope of -1 , bracketed by dot dash lines showing the $95 \%$ confidence interval), provided by Mark Zahniser at Aerodyn.

Two applications of fertilizers were subsequently supplied on 10 April (URAN-32-0-0 liquid nitrogen, $39 \mathrm{~kg} \mathrm{Nha}^{-1}$ ) and 14 May (URAN-32-0-0 liquid nitrogen, $79 \mathrm{~kg} \mathrm{~N} \mathrm{ha}^{-1}$ ). The experimental period was divided into four specific periods based on fertilization or precipitation events (Table 1). The first period started 24 days after the application of chicken litter, and the first liquid fertilizer application (URAN-32-00 , at a rate of $39 \mathrm{~kg} \mathrm{ha}^{-1}$ ) was within this period. The second period was characterized by the second fertilizer application and high precipitation. The third period was without fertilization and significant precipitation, and the fourth period had high relative precipitation but no fertilization. The data were further divided into two groups according to the measurement time: daytime (7 a.m. to 7 p.m.) and nighttime (7 p.m. to 7 a.m.). Mean and standard deviations of the $\mathrm{N}_{2} \mathrm{O}$ flux, soil moisture, and soil temperature were obtained and regression and correlation analysis were conducted for day and night for different temporal periods. In the regression analysis, soil moisture and temperature were independent variables and $\mathrm{N}_{2} \mathrm{O}$ flux was the dependent variable. The regression equations were used for filling gaps at the missing data points. The $\mathrm{N}_{2} \mathrm{O}$ flux was then integrated for the whole season to obtain the overall $\mathrm{N}_{2} \mathrm{O}$ emission. 
Table 1. Overview of four measurement periods characterized by precipitation and fertilization. Two fertilizer application events were on 10 April and 14 May 2012, respectively. Before the experiment, $99 \mathrm{~kg} \mathrm{Nha}^{-1}$ chicken litter was applied on 10 March; total precipitation was calculated as the sum of precipitation of each period.

\begin{tabular}{llcc}
\hline Index & Date & Fertilization $\mathrm{kg} \mathrm{Nha}^{-1}$ & Total precipitation $(\mathrm{mm})^{-}$ \\
\hline S1D & 4-25 April, day & 39 (URAN-32-0-0) & 15.73 \\
S1N & 4-25 April, night & - & 28.68 \\
S2D & 26 April-26 May, day & 79 (URAN-32-0-0) & 69.82 \\
S2N & 26 April-26 May, night & - & 96.23 \\
S3D & 27 May-24 June, day & - & 20.32 \\
S3N & 27 May-24 June, night & - & 8.62 \\
S4D & 25 June-8 August, day & - & 74.38 \\
S4N & 25 June-8 August, night & - & 53.56 \\
\hline
\end{tabular}

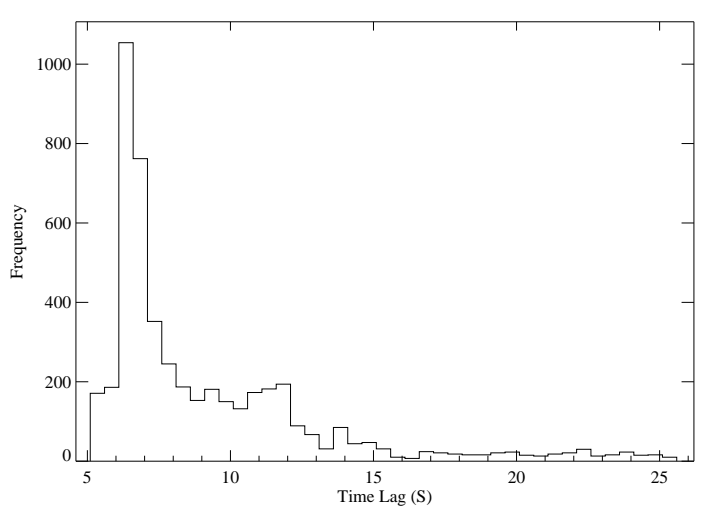

Figure 3. Whole-season histogram of the frequency distribution of time lags of $\mathrm{N}_{2} \mathrm{O}$ measurements from wind velocity measurements, found by searching the maximum of cross-covariance.

\section{Results}

\subsection{The performance of the $\mathrm{N}_{2} \mathrm{O}$ analyzer}

The precision of the $\mathrm{N}_{2} \mathrm{O}$ concentration measurements was characterized under field sampling conditions by the Allan variance technique (Fig. 2). In the log-log plot, the measurement variance decreased with the integration time $(t)$ with a slope of -1 when $t \leq 10 \mathrm{~s}$, indicating that there were no correlations between noise sources (pink noise) at time scales of 0.1 to $10 \mathrm{~s}$. The variance had a broad minimum between 10 and $100 \mathrm{~s}$ with a minimum corresponding to $0.006 \mathrm{ppbv}$ of standard deviation. The standard deviation was $0.066 \mathrm{ppbv}$ for $10 \mathrm{~Hz}$ (integration time $0.1 \mathrm{~s}$ ), $0.020 \mathrm{ppbv}$ for $1 \mathrm{~Hz}$ (integration time $1 \mathrm{~s}$ ), and $0.006 \mathrm{ppbv}$ for $0.1 \mathrm{~Hz}$ (integration time $10 \mathrm{~s})$.

Figure 3 shows the frequency distribution of time lags during the experimental period. The peak value of the distribution appeared at $\tau=6.3 \mathrm{~s}$, which represents the air flow time in the sampling tube between the field collection location and the QCL $\mathrm{N}_{2} \mathrm{O}$ analyzer.

Figure 4 shows sample cospectra of sensible heat and $\mathrm{N}_{2} \mathrm{O}$ and the theoretical $\mathrm{N}_{2} \mathrm{O}$ cospectra obtained during a windy day (Fig. 4a) and a windy night (Fig. 4b). A rather good performance of the $\mathrm{N}_{2} \mathrm{O}$ cospectrum in the low frequencies was demonstrated. The $\mathrm{N}_{2} \mathrm{O}$ cospectrum fell off faster at higher frequencies than the theoretical cospectrum and the sensible heat cospectrum. The $\mathrm{N}_{2} \mathrm{O}$ flux frequency loss ratios during the daytime and nighttime were low (1 and $2 \%)$. The frequency correction ratios by EddyPro for the daytime and nighttime were 18 and $19 \%$, respectively.

Table 2 shows the variation of the frequency loss ratio of $\mathrm{N}_{2} \mathrm{O}$ flux under weak to strong wind conditions $\left(u^{*}\right.$ is linearly related to wind speed). In general, the mean of flux frequency loss ratios (including all ratios: $\geq 0$ and $<0)$ increased with increased wind speed $\left(u^{*}\right)$ when $u^{*} \geq$ $0.2 \mathrm{~m} \mathrm{~s}^{-1}$. When $u^{*} \leq 0.2 \mathrm{~m} \mathrm{~s}^{-1}$, the eddies may not have been well enough developed for the measurements to be accurate. Under the nighttime condition, the frequency loss ratio was larger than under the daytime condition when the $u^{*}$ values were in the same category. The average EddyPro frequency correction ratio was 15 to $18 \%$.

\subsection{Seasonal variations}

A total of $519730 \mathrm{~min}$ data points were collected. After applying the two filters $\left(u^{*} \geq 0.2\right.$, precipitation-free), 1390 data points remained. In general, the concentration and the flux of $\mathrm{N}_{2} \mathrm{O}$ had higher values during and after the fertilizer application but gradually decreased with time, as shown in Figs. 5 and 6. However, rainfall (soil moisture) was a trigger for $\mathrm{N}_{2} \mathrm{O}$ emissions, which is the reason the flux reached peak values on the day of the largest application of URAN-32-0-0 (14 May), and the lack of peak values of $\mathrm{N}_{2} \mathrm{O}$ flux just after the first application with no rainfall. The growing season was characterized by a number of precipitation events which appeared to increase the $\mathrm{N}_{2} \mathrm{O}$ concentration as well as the $\mathrm{N}_{2} \mathrm{O}$ flux.

Note the two general seasonal concentration levels in Fig. 6. One was before a continuous corn canopy was established in early June, and the second, a continuous canopy that extended from mid-June to 8 August. These differences may have been caused by the high applications of the fer- 

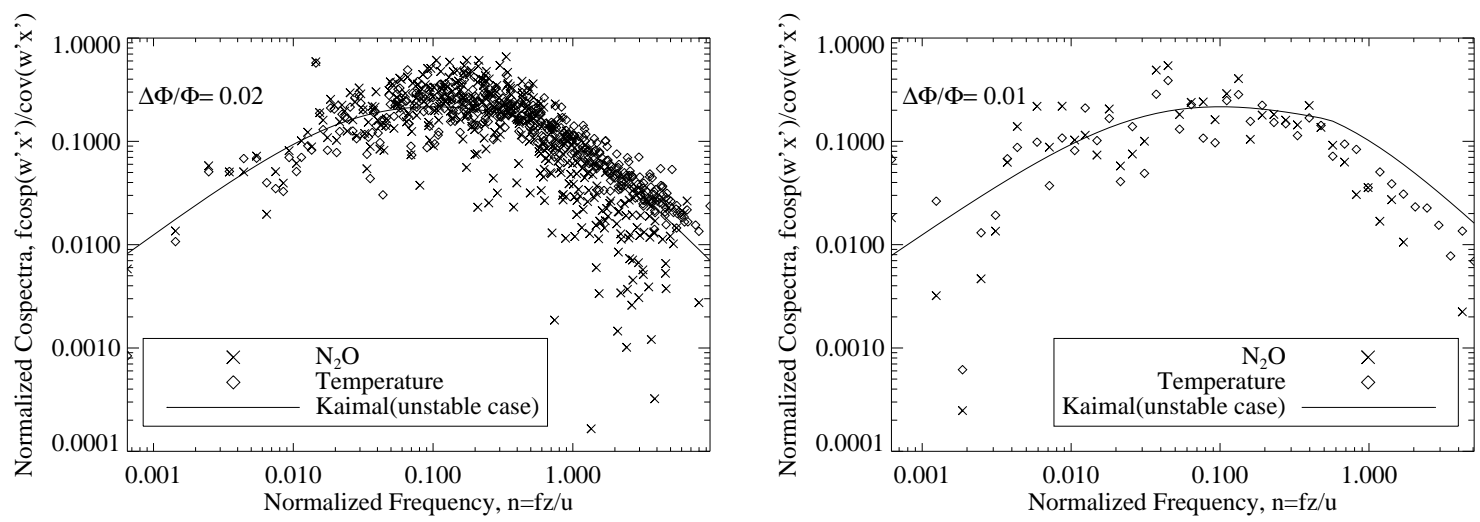

Figure 4. Normalized cospectra: on the left, daytime (7 a.m. to 7 p.m. 22 May 2012, $u^{*} \geq 0.2, L<0$ ); on the right, nighttime (7 p.m. 16 May to 7 a.m. 17 May 2012, $\left.u^{*} \geq 0.2, L<0\right)$. $L$ is the stability parameter: Obuckhov length (m) outputted from Eddypro; because under stable conditions $(L>0)$ the eddies may not have been well developed, the nighttime unstable conditions $(L<0)$ were chosen. The axis is normalized frequency: $n=f z / u$, where $f$ is natural frequency $(\mathrm{Hz}), z$ is measuring height $(\mathrm{m})$, and $u$ is wind speed (m s $\mathrm{s}^{-1}$ ). The idealized undamped cospectrum, according to Kaimal et al. (1972), and the sensible heat cospectrum are also given.

Table 2. Variation of frequency loss ratio $\frac{\Delta \varnothing}{\varnothing}$ and frequency loss correction ratio by EddyPro $\frac{\Delta \varnothing}{\varnothing}(\mathrm{EP})$ with friction velocity $\left(u^{*}, \mathrm{~m} \mathrm{~s}^{-1}\right)$ for May 2012. N/A: not available. Numbers in the cells are mean \pm standard deviations.

\begin{tabular}{|c|c|c|c|c|c|c|c|c|c|}
\hline \multirow{2}{*}{$\begin{array}{l}u^{*} \\
\text { Rang of Loss ratio }\end{array}$} & \multicolumn{3}{|l|}{$0 \leq u^{*}<0.1$} & \multicolumn{3}{|c|}{$0.1 \leq u^{*}<0.2$} & \multicolumn{3}{|c|}{$0.2 \leq u^{*}<0.3$} \\
\hline & $\geq \overline{0}$ & $<0$ & all & $\geq 0^{-}$ & $<0$ & all & $\geq 0^{-}$ & $<0$ & all \\
\hline \multicolumn{10}{|l|}{ Daytime } \\
\hline \# of samples & 16 & 18 & 34 & 84 & 65 & 149 & 113 & 140 & 253 \\
\hline & $0.43 \pm 0.48$ & $-0.42 \pm 0.48$ & $0.02 \pm 0.64$ & $0.33 \pm 0.55$ & $-0.45 \pm 1.10$ & $0.01 \pm 0.91$ & $0.43 \pm 1.29$ & $-0.39 \pm 1.64$ & $0.02 \pm 1.54$ \\
\hline$\frac{\Delta \varnothing}{\varnothing}(\mathrm{EP})$ & $0.16 \pm 0.01$ & $0.16 \pm 0.01$ & $0.16 \pm 0.01$ & $0.16 \pm 0.00$ & $0.15 \pm 0.00$ & $0.16 \pm 0.01$ & $0.16 \pm 0.01$ & $0.16 \pm 0.01$ & $0.16 \pm 0.01$ \\
\hline \multicolumn{10}{|l|}{ Nighttime } \\
\hline \# of samples & 145 & 91 & 236 & 47 & 12 & 59 & 4 & N/A & 4 \\
\hline & $0.76 \pm 1.35$ & $-0.84 \pm 1.66$ & $0.14 \pm 1.67$ & $0.90 \pm 1.09$ & $-0.23 \pm 0.26$ & $0.66 \pm 1.08$ & $0.42 \pm 0.27$ & N/A & $0.42 \pm 0.27$ \\
\hline$\frac{\Delta \varnothing}{\varnothing}(\mathrm{EP})$ & $0.16 \pm 0.01$ & $0.16 \pm 0.01$ & $0.16 \pm 0.01$ & $0.16 \pm 0.01$ & $0.16 \pm 0.00$ & $0.16 \pm 0.01$ & $0.16 \pm 0.01$ & N/A & $0.16 \pm 0.01$ \\
\hline$u^{*}$ & \multicolumn{3}{|c|}{$0.3 \leq u^{*}<0.4$} & \multicolumn{3}{|c|}{$0.4 \leq u^{*}<0.5$} & & & \\
\hline Rang of loss ratio & $\geq 0$ & $<0$ & all & $\geq 0$ & $<0$ & all & & & \\
\hline \multicolumn{10}{|l|}{ Daytime } \\
\hline \# of samples & 27 & 22 & 49 & 2 & N/A & 2 & & & \\
\hline & $0.22 \pm 0.22$ & $-0.37 \pm 0.67$ & $0.04 \pm 0.55$ & $0.31 \pm 0.29$ & N/A & $0.31 \pm 0.29$ & & & \\
\hline$\frac{\Delta \varnothing}{\varnothing}(\mathrm{EP})$ & $0.18 \pm 0.01$ & $0.17 \pm 0.01$ & $0.18 \pm 0.01$ & $0.16 \pm 0.01$ & N/A & $0.16 \pm 0.01$ & & & \\
\hline \multicolumn{10}{|l|}{ Nighttime } \\
\hline \# of samples & N/A & N/A & N/A & N/A & N/A & N/A & & & \\
\hline & N/A & N/A & N/A & N/A & N/A & N/A & & & \\
\hline$\frac{\Delta \varnothing}{\varnothing}(\mathrm{EP})$ & N/A & N/A & N/A & N/A & N/A & N/A & & & \\
\hline
\end{tabular}

tilizer and less nitrogen use by the establishing crop before June, which resulted in higher soil $\mathrm{N}$ availability and more $\mathrm{N}_{2} \mathrm{O}$ emissions during that period (as shown in Fig. 5).

\subsection{Diurnal variations}

Diurnal variations of the $\mathrm{N}_{2} \mathrm{O}$ flux were detected (Figs. 7 and 8). Figure 7 contains nearly complete diurnal data for each day for 5 selected days $\left(>20 \mathrm{~h}\right.$ data per day and $u^{*} \geq$ $\left.0.2 \mathrm{~m} \mathrm{~s}^{-1}\right)$. The peak flux commonly appeared during the daytime, whereas the flux was low at night, except for the third sub-period in Fig. 8 when soil moisture was high during the nighttime. The average daytime and nighttime $\mathrm{N}_{2} \mathrm{O}$ fluxes during the 5 days were $96.4 \pm 11.7 \mu \mathrm{g} \mathrm{N}_{2} \mathrm{O}$ $\mathrm{N} \mathrm{m}^{-2} \mathrm{~h}^{-1}$ and $59.0 \pm 13.0 \mu \mathrm{g} \mathrm{N}_{2} \mathrm{O}-\mathrm{N} \mathrm{m}^{-2} \mathrm{~h}^{-1}$, respectively. The average flux was about $63 \%$ higher during the daytime than during the nighttime (Fig. 7). The average daytime and nighttime $\mathrm{N}_{2} \mathrm{O}$ fluxes during the whole season were $278.8 \pm 47.5$ and $99.9 \pm 29.8 \mu \mathrm{g} \mathrm{N} \mathrm{N}_{2} \mathrm{O}-\mathrm{N} \mathrm{m}^{-2} \mathrm{~h}^{-1}$, re- 


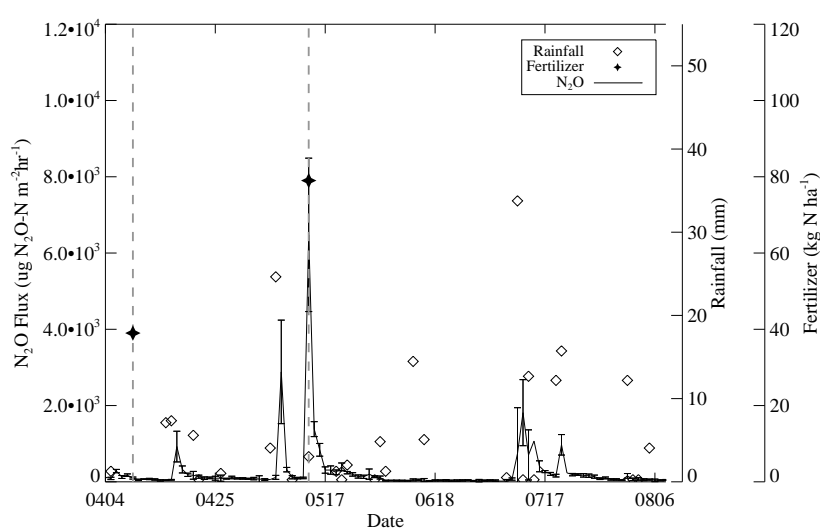

Figure 5. Daily average $\mathrm{N}_{2} \mathrm{O}$ flux $\left(\mu \mathrm{g} \mathrm{N}_{2} \mathrm{O}-\mathrm{N} \mathrm{m}^{-2} \mathrm{~h}^{-1}\right)$ with rainfall and $\mathrm{N}$ fertilizer applications from 4 April to 8 August 2012. Error bars were the standard deviations of all data collected on each day $\left(u^{*} \geq 0.2 \mathrm{~m} \mathrm{~s}^{-1}\right)$.

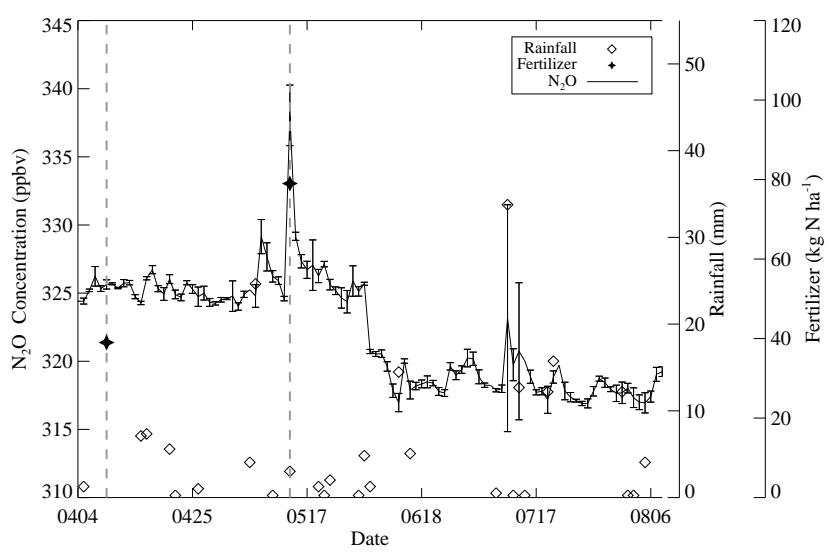

Figure 6. Daily average $\mathrm{N}_{2} \mathrm{O}$ concentration (ppbv) with rainfall and $\mathrm{N}$ fertilizer applications from 4 April to 8 August 2012. Error bars were the standard deviations of all data collected on each day $\left(u^{*} \geq\right.$ $0.2 \mathrm{~m} \mathrm{~s}^{-1}$ ).

spectively (all the "mean \pm number" in this paper are $95 \%$ confidence intervals unless otherwise noted). This diurnal response was most likely a temperature response.

\subsection{Result statistics}

The $\mathrm{N}_{2} \mathrm{O}$ concentrations and fluxes were highly variable with time. The concentration was $322.8 \pm 0.3 \mathrm{ppbv}$ with a coefficient of variation (CV) of $1.24 \%$. The $\mathrm{N}_{2} \mathrm{O}$ flux ranged from 0.0 to event-related emissions as high as $11100 \mu \mathrm{g} \mathrm{N} \mathrm{N}_{2} \mathrm{O}-\mathrm{N} \mathrm{m}^{-2} \mathrm{~h}^{-1}$, with a CV of $317.6 \%$ and a mean of $257.5 \pm 817.7 \mu \mathrm{g} \mathrm{N}_{2} \mathrm{O}-\mathrm{Nm}^{-2} \mathrm{~h}^{-1}$. As shown in Table 3, nearly $90 \%$ of the data were obtained during the daytime. Fluxes were higher during the daytime than during the night (Table 3 and Fig. 7). For the whole experimental period, the total emission was $6.87 \mathrm{~kg} \mathrm{~N}_{2} \mathrm{O}-\mathrm{N} \mathrm{ha}^{-1}$ (Fig. 9).

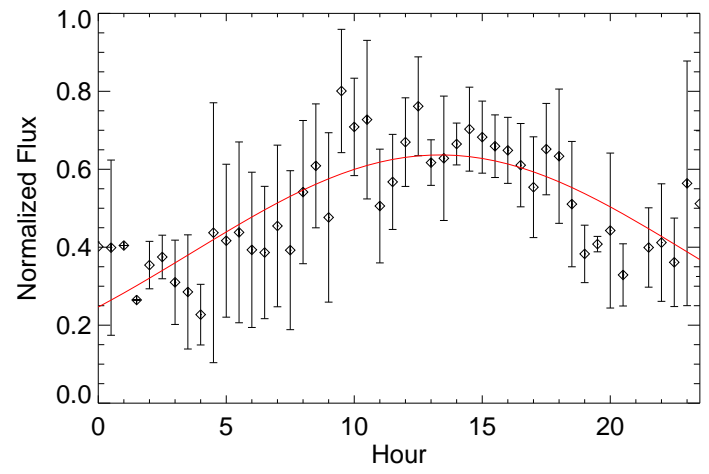

Figure 7. Diurnal variation of $\mathrm{N}_{2} \mathrm{O}$ flux for the four sub-periods defined in Table 1, (a) the first period, (b) the second period, (c) the third period, and (d) the fourth period. $r_{\mathrm{st}}$ is the correlation coefficient of $\mathrm{N}_{2} \mathrm{O}$ flux and soil temperature; $r_{\mathrm{sm}}$ is the correlation coefficient of $\mathrm{N}_{2} \mathrm{O}$ flux and soil moisture.

\subsection{Effects of soil moisture, temperature, and $\mathrm{N}$ availability on $\mathrm{N}_{2} \mathrm{O}$ emissions}

Figure 10 presents an overview of the measured concentration and flux for the whole experimental period, together with soil temperature and soil moisture. Generally, the variations of $\mathrm{N}_{2} \mathrm{O}$ concentration and flux followed most closely the pattern of variation of soil moisture. As expected, concentrations and fluxes were usually elevated immediately after precipitation events. As shown in Table 1, there was no fertilization event or significant precipitation in the third period, and thus the $\mathrm{N}_{2} \mathrm{O}$ flux was constantly low.

In previous studies it has been difficult to generalize and interpret the relationship of $\mathrm{N}_{2} \mathrm{O}$ emissions to soil temperature or soil moisture quantitatively because in each specific study the determinants are different. In this study, for the entire experimental period, the $\mathrm{N}_{2} \mathrm{O}$ flux was positively correlated to soil moisture with a Pearson correlation coefficient $r$ of $0.42(p<0.001)$, while the correlation with soil temperature was poor $(r=-0.079, p=0.003)$. Table 4 shows the Pearson correlation coefficients for the periods defined in Table 1 . The $\mathrm{N}_{2} \mathrm{O}$ flux was significantly correlated with soil moisture with the exception of $\mathrm{S} 1 \mathrm{~N}$, which was probably limited by the small sample size. These correlations indicate that on this site the dominant driver of $\mathrm{N}_{2} \mathrm{O}$ emissions was soil moisture in addition to substrate $\mathrm{N}$ availability.

Although the soil temperature did not positively correlate to the seasonal $\mathrm{N}_{2} \mathrm{O}$ emission, it was significantly and positively correlated to the diurnal (hourly) $\mathrm{N}_{2} \mathrm{O}$ emission during the first and second sub-periods (correlation coefficient $r_{\mathrm{st}}=0.76$ and $\left.0.56, p<0.001\right)$ when soil moisture was not strongly predictive $\left(r_{\mathrm{sm}}<0.36, p>0.05\right)$ (Fig. 8). Therefore, the peak flux during these sub-periods appeared most often during the day, when the soil temperature was relatively high compared to the night. However, during times of significant effects of soil moisture $\left(r_{\mathrm{sm}}>0.45, p<0.05\right)$ during the 

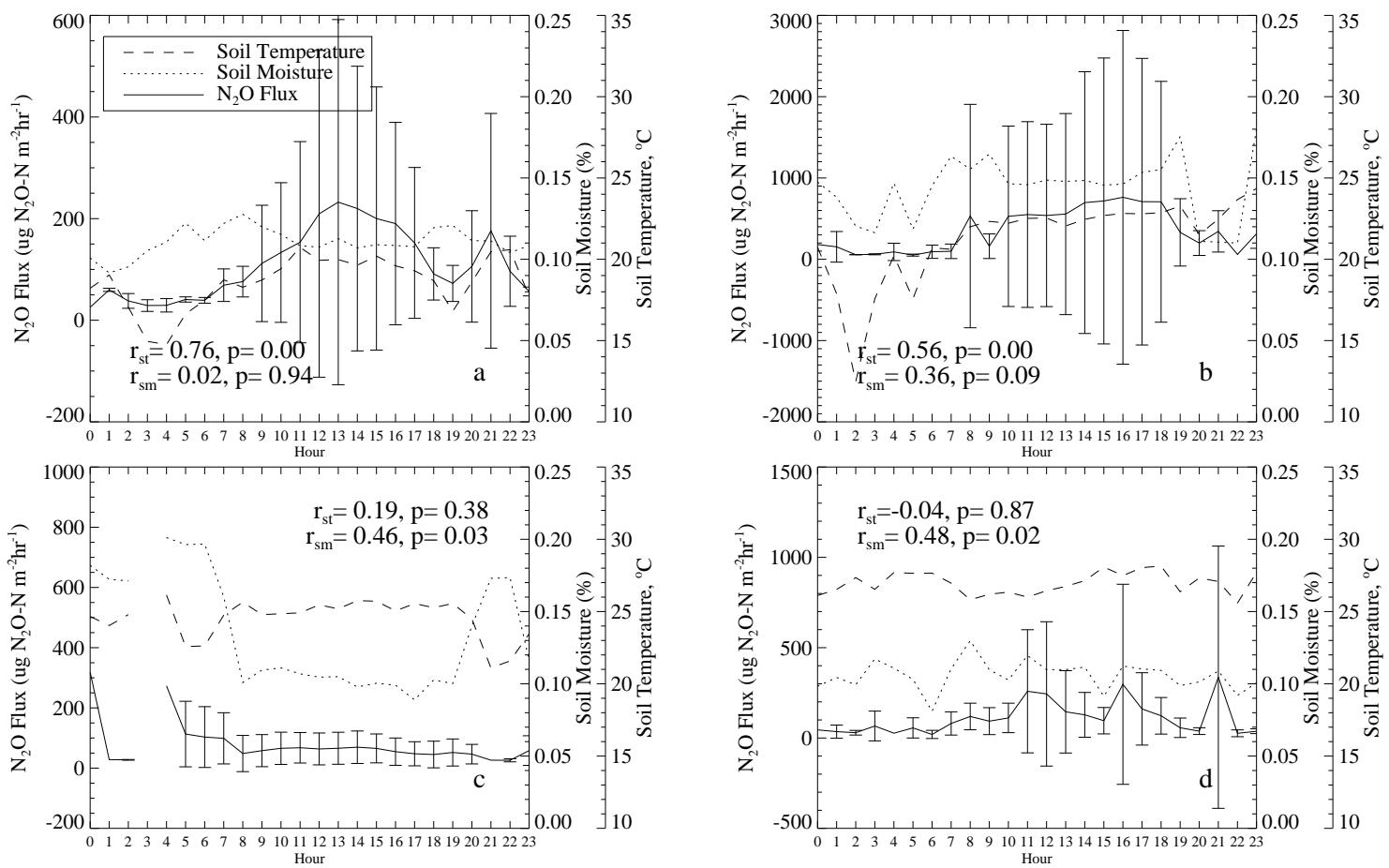

Figure 8. Diurnal variation of $30 \mathrm{~min} \mathrm{~N}_{2} \mathrm{O}$ flux for the four sub-periods defined in Table 1: (a) the first period, (b) the second period, (c) the third period, and (d) the fourth period. $r_{\mathrm{st}}$ is the correlation coefficient of $\mathrm{N}_{2} \mathrm{O}$ flux and soil temperature; $r_{\mathrm{sm}}$ is the correlation coefficient of $\mathrm{N}_{2} \mathrm{O}$ flux and soil moisture.

Table 3. Descriptive statistics for $30 \mathrm{~min}_{2} \mathrm{O}$ concentration and flux for the period of experiment, 4 April-8 August $2012\left(u^{*} \geq 0.2 \mathrm{~m} \mathrm{~s}{ }^{-1}\right.$ ). Nonparametric boot-strapping procedure was used to obtain the $95 \%$ confidence interval.

\begin{tabular}{|c|c|c|c|c|c|}
\hline & \multirow{2}{*}{$\begin{array}{c}\text { Number } \\
\text { of samples }\end{array}$} & \multicolumn{2}{|r|}{ Concentration (ppbv) } & \multicolumn{2}{|c|}{ Flux $\left(\mu \mathrm{g} \mathrm{N}_{2} \mathrm{O}-\mathrm{Nm}^{-2} \mathrm{~h}^{-1}\right)$} \\
\hline & & Mean & $95 \%$ Confidence interval & Mean & $95 \%$ Confidence interva \\
\hline Daytime & 1224 & 322.9 & \pm 0.2 & 278.8 & \pm 47.5 \\
\hline Nighttime & 166 & 322.5 & \pm 0.6 & 99.9 & \pm 29.8 \\
\hline Total & 1390 & 322.8 & \pm 0.3 & 257.5 & \pm 42.9 \\
\hline
\end{tabular}

third and fourth sub-periods, the temperature effects on the $\mathrm{N}_{2} \mathrm{O}$ flux was not significant $\left(r_{\mathrm{st}}<0.2, p>0.05\right)$.

Several studies have found that $\mathrm{N}_{2} \mathrm{O}$ flux increased exponentially with soil temperature (Dinsmore et al., 2009; Schindlbacher et al., 2004; Smith et al., 2003). At first we regressed the observed $\mathrm{N}_{2} \mathrm{O}$ flux with soil temperature and soil moisture following the exponential functions given by Luo et al. (2013). However, for some periods the coefficients of determination $\left(R^{2}\right)$ were low $(<0.4)$. Then we regressed the $\mathrm{N}_{2} \mathrm{O}$ flux with soil temperature and soil moisture using exponential or polynomial functions (Table 5). The values of $R^{2}$ ranged from 0.45 to 0.70 . For most of the periods, soil moisture explained a significant amount of the variation in $\mathrm{N}_{2} \mathrm{O}$ emissions.

$\mathrm{N}$ availability was an important factor in $\mathrm{N}_{2} \mathrm{O}$ emissions. The fertilizer amount of the second application was more than twice that of the first application; the large amount of fertilizer provided sufficient $\mathrm{N}$. The volume concentration of $\mathrm{NO}_{3}^{-}$in the top $10 \mathrm{~cm}$ of soil was 5.5 parts per million (ppmv) on 15 April and was 8.5 ppmv on 16 May. The concentrations of $\mathrm{NH}_{4}^{+}$were $16 \mathrm{ppmv}$ and $19.5 \mathrm{ppmv}$ for these 2 days, respectively. The higher mineral $\mathrm{N}$ concentration most likely contributed to the dramatic increase in $\mathrm{N}_{2} \mathrm{O}$ concentration and flux after the second application.

\section{Discussion}

\section{1 $\quad \mathrm{N}_{2} \mathrm{O}$ analyzer performance}

Several studies have been performed for $\mathrm{N}_{2} \mathrm{O}$ measurements using QCL spectrometers over grassland or forest (Neftel et al., 2010, 2007; Eugster et al., 2007; Kroon et al., 2007; Nelson et al., 2004). Besides experimental locations, seasons, and/or crop types, the instruments utilized in these studies 
Table 4. Statistical results of $30 \mathrm{~min}$ soil temperature $\left({ }^{\circ} \mathrm{C}\right)$, soil moisture $(\%)$, and $\mathrm{N}_{2} \mathrm{O}$ flux $\left(\mu \mathrm{g} \mathrm{N} \mathrm{N}_{2} \mathrm{O}-\mathrm{N} \mathrm{m}^{-2} \mathrm{~h}^{-1}\right)\left(\mathrm{mean}^{-} 95 \%\right.$ confidence interval), as well as Pearson correlation coefficients and $p$ value $[r(p)]$ of $\mathrm{N}_{2} \mathrm{O}$ flux with soil temperature or soil moisture $\left(u^{*} \geq 0.2 \mathrm{~m} \mathrm{~s}{ }^{-1}\right)$. N/A: not available.

\begin{tabular}{|c|c|c|c|c|c|c|c|}
\hline Date & Fertilizer application & $\begin{array}{l}\text { Number } \\
\text { of samples }\end{array}$ & $\begin{array}{l}\text { Soil } \\
\text { temperature }\end{array}$ & $\begin{array}{l}\text { Soil } \\
\text { moisture }\end{array}$ & Flux & $\begin{array}{r}\text { Soil } \\
\text { temperature } r(p)\end{array}$ & $\begin{array}{r}\text { Soil } \\
\text { moisture } r(p)\end{array}$ \\
\hline & $\mathrm{kgNha}^{-1}$ & & ${ }^{\circ} \mathrm{C}$ & $\%$ & $\mu \mathrm{g} \mathrm{N}_{2} \mathrm{O}-\mathrm{N} \mathrm{m}^{-2} \mathrm{~h}^{-1}$ & & \\
\hline $10 \mathrm{March}$ & 99 (chicken litter) & N/A & & & & & \\
\hline 4-25 April, day & 39 (URAN-32-0-0) & 274 & $18.0 \pm 0.4$ & $11.8 \pm 0.3$ & $173.3 \pm 27.9$ & $0.18(0.00)$ & $0.61(0.00)$ \\
\hline 4-25 April, night & & 48 & $18.9 \pm 0.6$ & $9.1 \pm 0.4$ & $62.7 \pm 20.1$ & $0.45(0.00)$ & $0.07(0.65)$ \\
\hline 26 April-26 May, day & 79 (URAN-32-0-0) & 392 & $23.2 \pm 0.2$ & $15.0 \pm 0.4$ & $602.5 \pm 141.9$ & $-0.20(0.00)$ & $0.49(0.00)$ \\
\hline 26 April-26 May, night & & 35 & $21.9 \pm 0.9$ & $12.0 \pm 1.1$ & $173.5 \pm 69.9$ & $0.50(0.00)$ & $0.64(0.00)$ \\
\hline 27 May-24 June, day & & 326 & $24.9 \pm 0.2$ & $11.1 \pm 0.5$ & $60.8 \pm 5.6$ & $-0.19(0.00)$ & $0.78(0.00)$ \\
\hline 27 May-24 June, night & & 36 & $26.1 \pm 0.4$ & $12.0 \pm 1.7$ & $88.4 \pm 49.6$ & $0.15(0.39)$ & $0.61(0.00)$ \\
\hline 25 June- 8 August, day & & 232 & $27.1 \pm 0.2$ & $10.5 \pm 0.5$ & $162.2 \pm 34.5$ & $-0.25(0.00)$ & $0.57(0.00)$ \\
\hline 25 June- 8 August, night & & 47 & $28.8 \pm 0.4$ & $8.2 \pm 1.1$ & $92.3 \pm 75.4$ & $-0.49(0.00)$ & $0.53(0.00)$ \\
\hline Whole experimental period, day & & 1224 & $23.2 \pm 0.2$ & $12.4 \pm 0.3$ & $279.0 \pm 48.1$ & $-0.08(0.00)$ & $0.42(0.00)$ \\
\hline Whole experimental period, night & & 166 & $23.9 \pm 0.7$ & $10.2 \pm 0.6$ & $100.1 \pm 36.4$ & $0.05(0.56)$ & $0.50(0.00)$ \\
\hline
\end{tabular}

Table 5. 30 min $\mathrm{N}_{2} \mathrm{O}$ flux $\left(\mu \mathrm{g} \mathrm{N} \mathrm{O}_{2} \mathrm{O}-\mathrm{N} \mathrm{m}^{-2} \mathrm{~h}^{-1}\right)$ regression equations $(p<0.01)$ with soil moisture $(\mathrm{SM}, \%)$ and soil temperature $\left(\mathrm{ST},{ }^{\circ} \mathrm{C}\right)$ $\left(u^{*} \geq 0.2 \mathrm{~ms}^{-1}\right)$.

\begin{tabular}{lllll}
\hline Date & Day equation & $R^{2}$ & Night equation & $R^{2}$ \\
\hline 4-25 April & $20.16 \mathrm{e}^{19.398 \mathrm{SM}}$ & 0.45 & $-137.736+5.6448 \mathrm{SM}+564.48 \mathrm{ST}$ & 0.62 \\
26 April-26 May & $\begin{array}{l}209037600 \mathrm{SM}^{4}-11612160 \mathrm{SM}^{3}+2360304 \mathrm{SM}^{2} \\
-191720 \mathrm{SM}+66185.28\end{array}$ & 0.68 & $18 \mathrm{e}^{16.479 S M}$ & 0.45 \\
& $\begin{array}{l}66154.68 \mathrm{SM}^{3}-137696.28 \mathrm{SM}^{2}+967.68 \mathrm{SM} \\
\text { 27 May-24 June }\end{array}$ & 0.71 & $6.048 \mathrm{e}^{16.308 S M}$ & 0.70 \\
& $\begin{array}{l}\text { +10.08 } \\
\text { 25 June-8 August }\end{array}$ & $0.16 \mathrm{e}^{18.349 \mathrm{SM}}$ & $0.5 \mathrm{e}^{23.113 \mathrm{SM}}$ & 0.54 \\
\hline
\end{tabular}

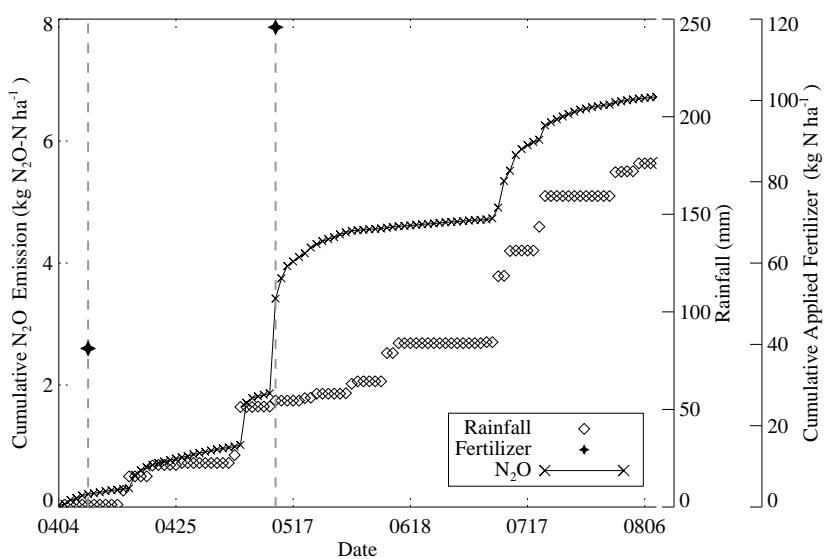

Figure 9. Cumulative $\mathrm{N}_{2} \mathrm{O}$ emission for the experimental site from 4 April to 8 August 2012. Rainfall and $\mathrm{N}$ fertilizer applications data are also shown; 24 days before the experiment (10 March), chicken litter was applied at a rate of $99 \mathrm{~kg} \mathrm{~N} \mathrm{ha}^{-1}$ (not shown in the figure).

differed from each other in terms of absorption line and precision. For example, in the studies of Kroon et al. (2007) and Neftel et al. (2010), $\mathrm{N}_{2} \mathrm{O}$ was measured at wavelengths of $1271.1 \mathrm{~cm}^{-1}$ and $1275.5 \mathrm{~cm}^{-1}$, respectively, while in Neftel et al. (2007) and Eugster et al. (2007), $\mathrm{N}_{2} \mathrm{O}$ was measured at $2241.0 \mathrm{~cm}^{-1}$ and $2243.1 \mathrm{~cm}^{-1}$, respectively. The precision of the instruments in these four studies, at a sampling rate of $1 \mathrm{~Hz}$, was $0.5,0.7,0.3$, and $0.3 \mathrm{ppbv}$, respectively. In our study, the precision was $0.02 \mathrm{ppbv}$ at $1 \mathrm{~Hz}$.

The detection limits of the EC flux were calculated as the standard deviations of the cross covariances between vertical wind fluctuations and gas concentration fluctuations far outside of the true time lag $(-200 \mathrm{~s} \leq \tau \leq-50 \mathrm{~s})$ (Neftel et al., 2010, Wienhold et al., 1995). Thus the EC detection limits derived from this method were not a constant value and were dependent on the instruments and atmospheric conditions. The mean detection limit in this study was $7.56 \mu \mathrm{g} \mathrm{N} \mathrm{m}^{-2} \mathrm{~h}^{-1}$, which was less than half of the $\mathrm{N}_{2} \mathrm{O}$ flux detection limit of $17.13 \mu \mathrm{g} \mathrm{N} \mathrm{m}^{-2} \mathrm{~h}^{-1}$ as reported in Neftel et al. (2010) and of $21.60 \mu \mathrm{g} \mathrm{N} \mathrm{m}^{-2} \mathrm{~h}^{-1}$ as reported in Kroon et al. (2007).

It has been shown that the sensible heat cospectrum calculated from sonic temperatures experiences almost no damping (Neftel et al., 2010; Kroon et al., 2007) (Fig. 4a and b). Therefore, an empirical correction approach can be used based on a comparison of the sensible heat cospectrum and $\mathrm{N}_{2} \mathrm{O}$ cospectrum to correct the high frequency loss (Neftel et al., 2010; Kroon et al., 2007).

Neftel et al. (2010), under a wind speed of 0.8 to $2 \mathrm{~m} \mathrm{~s}^{-1}$, reported a 14 to $30 \%$ frequency loss correction ratio compared to a mean correction ratio of $16 \%$ by EddyPro in 


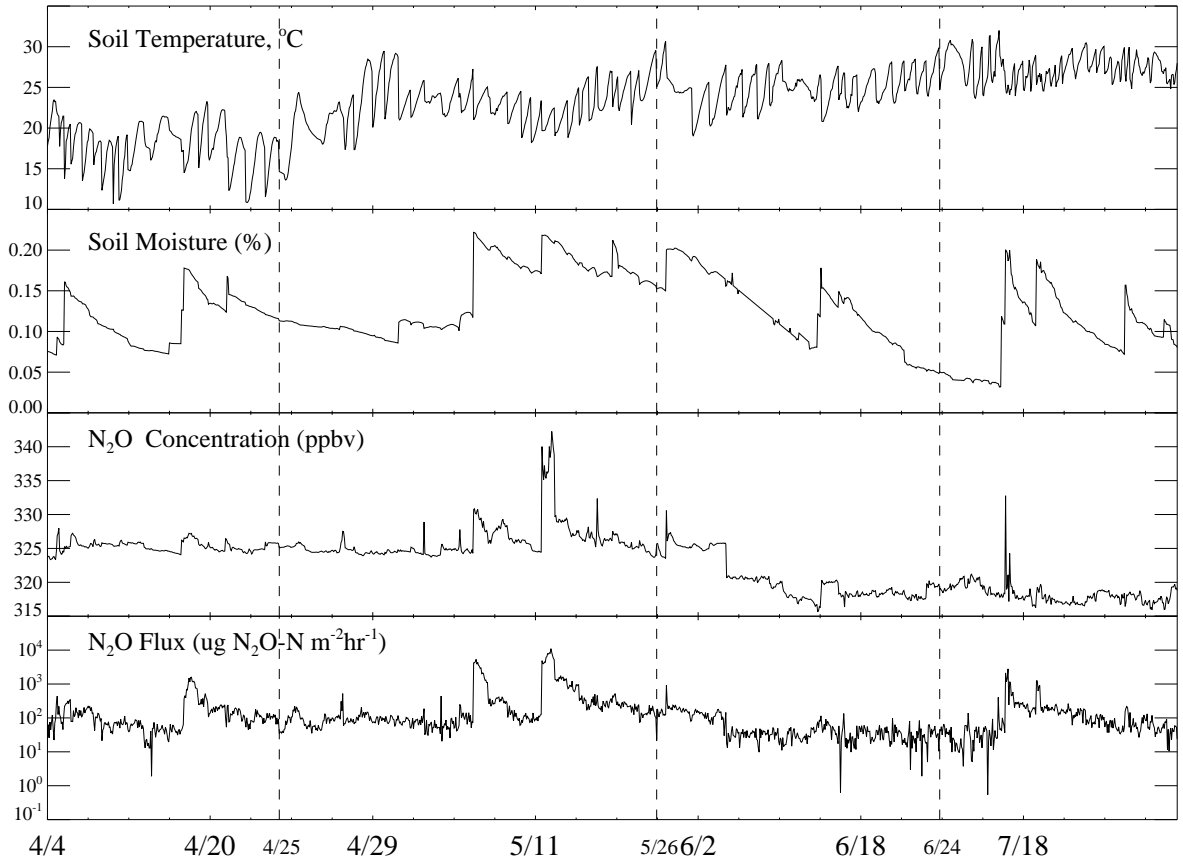

Figure 10. Time series of $30 \mathrm{~min}$ soil temperature, soil moisture, $\mathrm{N}_{2} \mathrm{O}$ concentration, and flux for the whole experimental period. The vertical dashed lines indicate the sub-periods defined in Table 1.

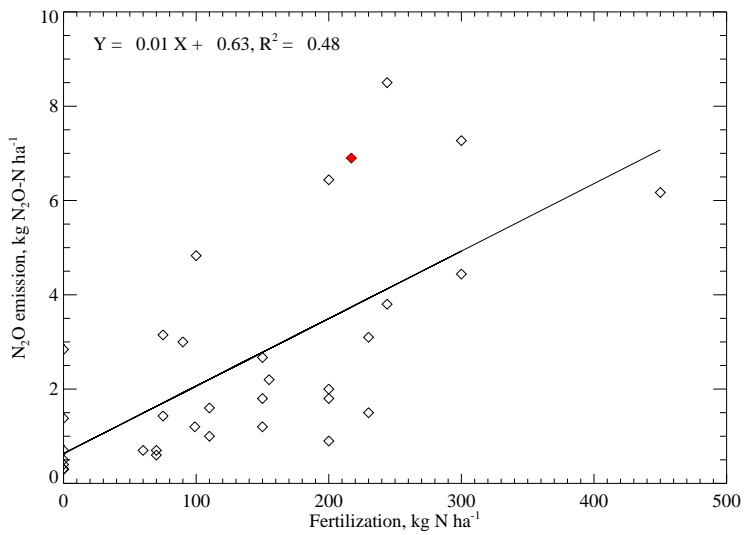

Figure 11. Regression of cumulative $\mathrm{N}_{2} \mathrm{O}$ emission on the total applied fertilizer $\mathrm{N}$ in 10 different studies (where both amount of fertilizer and cumulative $\mathrm{N}_{2} \mathrm{O}$ emission are provided) listed in Table 6; the result of this study is indicated by the red square.

this study (corresponding to $u^{*}=0.2$ to $0.5 \mathrm{~m} \mathrm{~s}^{-1}$ ). Neftel et al. (2010) used vapor cospectra to correct the frequency loss, whereas this study used the methods in Ibrom et al. (2007), Horst and Lenschow (2009), and Moncrieff et al. (2004), which may account for the difference in frequency loss correction ratios.

About $93 \%$ of the valid data $\left(u^{*} \geq 0.2 \mathrm{~m} \mathrm{~s}^{-1}\right)$ in this study were under wind conditions of $0.4 \mathrm{~m} \mathrm{~s}^{-1}>u^{*} \geq 0.2 \mathrm{~m} \mathrm{~s}^{-1}$ and were in the daytime, when the corresponding mean frequency loss ratio was low, between 2 and $4 \%$. Therefore, the flux may have been overestimated because the mean frequency correction ratio was 16-18\% (Table 2).

The mean of the positive frequency loss ratios was greater than $22 \%$ and the mean of the negative loss ratios was smaller than $-37 \%$ (for $u^{*} \geq 0.2 \mathrm{~m} \mathrm{~s}^{-1}$ ) (Table 2). The negative and the positive ratios canceled out each other and resulted in the mean 2 to $4 \%$ frequency loss ratios. Therefore, for long-term $\mathrm{N}_{2} \mathrm{O}$ flux measurements, the mean frequency loss may be low.

\section{2 $\quad \mathrm{N}_{2} \mathrm{O}$ emission compared with the literature}

A number of studies have been carried out to investigate $\mathrm{N}_{2} \mathrm{O}$ emissions from the soil into the atmosphere, and the results reported in the literature show tremendous variation (Table 6). Previous studies have shown that the $\mathrm{N}_{2} \mathrm{O}$ emission depends on several factors including precipitation, fertilization, tillage, crop type, soil factor, and instrumentation (Ussiri et al., 2009; Wagner-Riddle et al., 2007). Fertilizer application was a prime factor causing a different $\mathrm{N}_{2} \mathrm{O}$ emission in previous studies. Generally, the measured flux and cumulative emission were larger with a larger amount of fertilizer application (Table 6). In order to obtain a gross synthesization of these previous studies, shown in Table 6, and how this study fits into them, we plotted those which reported both fertilizer applied and the integrated amount of $\mathrm{N}_{2} \mathrm{O}$ emissions. Figure 11 presents a simple linear plot of emissions $\left(\mathrm{kg} \mathrm{N}_{2} \mathrm{O}-\mathrm{N} \mathrm{ha}^{-1}\right.$ ) (Table 6, column 9) as a function of fertilizer applied $\left(\mathrm{kg} \mathrm{Nha}^{-1}\right)$ (Table 6, column 6). The graph demonstrates a general linear trend $\left(R^{2}=0.48, p<0.001\right)$ of 
Table 6. Summary of $\mathrm{N}_{2} \mathrm{O}$ measurements in literature (mean flux or flux range and cumulative emission), EC indicates eddy covariance method, "-" indicates data or information are not available directly from the reference.

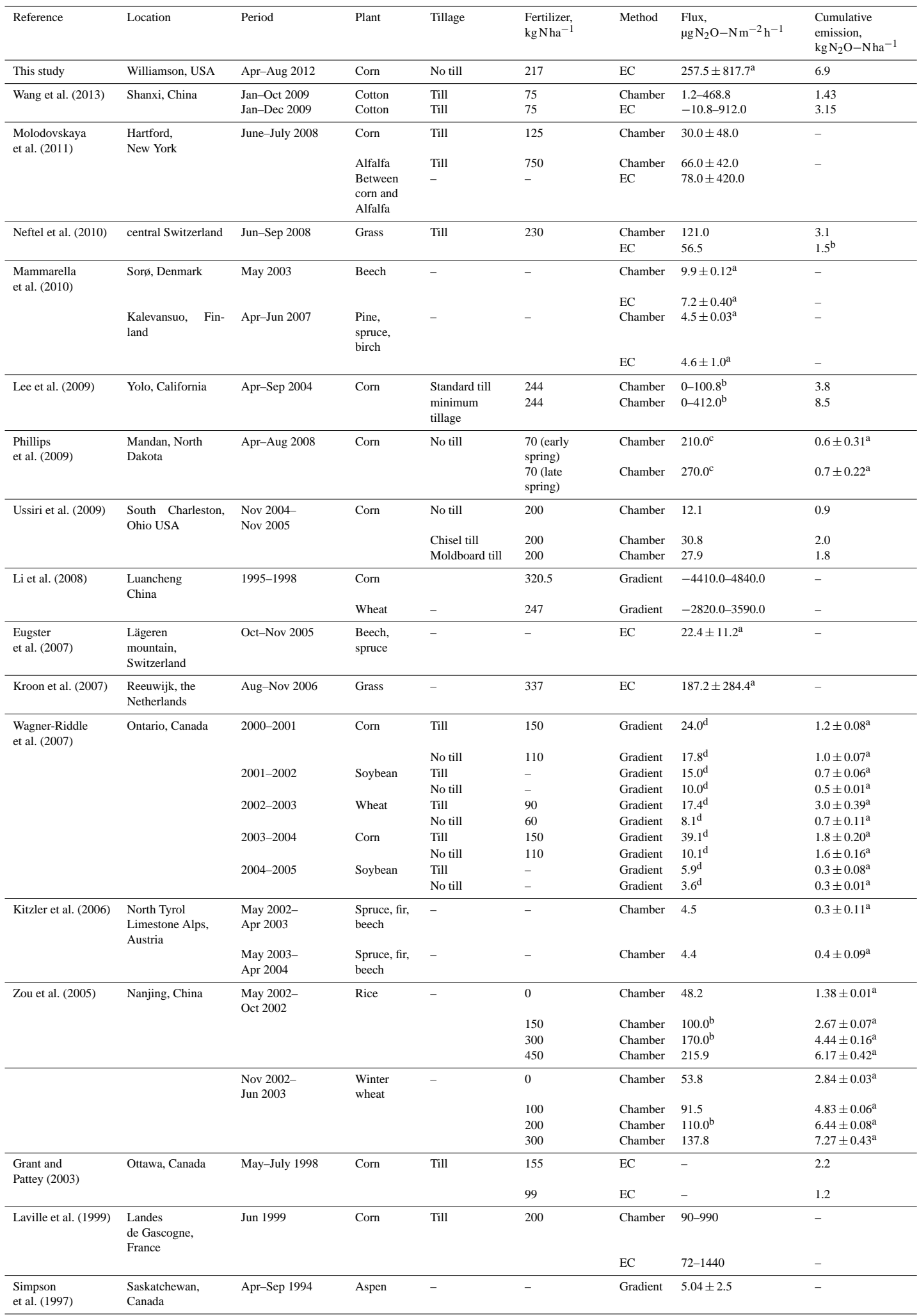

${ }^{a}$ Standard deviations.

$\mathrm{b}$ Values are not given directly, calculated from known variables.

${ }^{\mathrm{c}}$ The measurements were taken at 10-12:00 Central (CST) (UTC-6) daily and used as the daily flux.

$\mathrm{d}$ Median instead of mean. 
increasing emissions with increased amounts of $\mathrm{N}$ fertilizer, without regard to soil moisture, crop type, tillage, crop management, measurement techniques, or length of time of the study. The simple linear regression shows the ratio of $\mathrm{N}_{2} \mathrm{O}$ emissions to $\mathrm{N}$ fertilizer to be 0.0143 . Thus, in general, it appears that $1.43 \%$ of each unit of $\mathrm{N}$ fertilizer applied is emitted to the atmosphere as $\mathrm{N}_{2} \mathrm{O}$.

Corn crops were reported in nine of the studies listed in Table 6. They fit the trends described above. Similar amounts of fertilizers were applied in Lee et al. (2009) and Laville et al. (1999) as in this study, and similar orders of $\mathrm{N}_{2} \mathrm{O}$ emission were observed in all three. Where lower applications of fertilizer were reported for corn fields (Molodovskaya et al., 2011; Phillips et al., 2009; Ussiri et al., 2009; Wagner-Riddle et al., 2007, and Grant and Pattey 2003), lower $\mathrm{N}_{2} \mathrm{O}$ emissions were measured.

In addition to fertilization, tillage also has played a role in governing $\mathrm{N}_{2} \mathrm{O}$ emissions. Lee and colleagues (Lee et al., 2009) showed that with the same amounts of fertilizers for corn, sunflower, and chickpea, different tillage could cause differences in $\mathrm{N}_{2} \mathrm{O}$ emissions. Fully tilled fields tended to release less $\mathrm{N}_{2} \mathrm{O}$.

In general, forest $\mathrm{N}_{2} \mathrm{O}$ emissions have been lower than those from agriculture, which was probably due to the large amount of fertilizers applied to farmland. For example, compared to the flux rate $257.5 \pm 42.9 \mu \mathrm{g} \mathrm{N}_{2} \mathrm{O}-\mathrm{N} \mathrm{m}^{-2} \mathrm{~h}^{-1}$ in this study, Mammarella et al. (2010) measured an averaged flux of $\sim 10 \mu \mathrm{g} \mathrm{N} \mathrm{N}_{2} \mathrm{O}-\mathrm{N} \mathrm{m}^{-2} \mathrm{~h}^{-1}$ during 2 May to 5 June 2003 in a beech forest of Denmark. They showed $\sim 5 \mu \mathrm{g} \mathrm{N} \mathrm{N}_{2} \mathrm{O}$ $\mathrm{N} \mathrm{m}^{-2} \mathrm{~h}^{-1}$ flux during the spring of 2007 in a forest with pine, small-sized spruce, and birch in southern Finland, using both the EC and chamber methods. Eugster et al. (2007) measured $\mathrm{N}_{2} \mathrm{O}$ from a forest mixed with beech and spruce using the EC method. The reported flux was $22.4 \pm 11.2 \mu \mathrm{g} \mathrm{N} \mathrm{N}_{2} \mathrm{O}-$ $\mathrm{N} \mathrm{m}^{-2} \mathrm{~h}^{-1}$.

\subsection{Effects of soil moisture, temperature, and $\mathrm{N}$ availability on $\mathrm{N}$ emissions}

Soil moisture is a major factor for $\mathrm{N}_{2} \mathrm{O}$ emissions (Table 4). As indicated by Dobbie and Smith (2003) and Davidson (1991), $\mathrm{N}_{2} \mathrm{O}$ emitted from soil is caused principally by the microbial nitrogen transformations during both nitrification and denitrification. These processes are closely related to WFPS, since denitrification is an anaerobic process that depends on the balance between the amount of water entering and leaving the soil. Several studies have confirmed that there are connections between increased $\mathrm{N}_{2} \mathrm{O}$ emissions and precipitation (Zona et al., 2011; Jungkunst et al., 2008; Neftel et al., 2007). In this study, after the first application of fertilizer, precipitation did not occur immediately and there was no significant change in $\mathrm{N}_{2} \mathrm{O}$ flux. On the day of the second application, the total precipitation was $3.02 \mathrm{~mm}$ and peak values of $\mathrm{N}_{2} \mathrm{O}$ fluxes occurred immediately after the precipitation event (Fig. 5). The difference in $\mathrm{N}_{2} \mathrm{O}$ emission response after first and second applications of fertilizer showed the trigger effect of precipitation on the $\mathrm{N}_{2} \mathrm{O}$ emission. The other notable feature of Fig. 5 was the remarkable increases of $\mathrm{N}_{2} \mathrm{O}$ for the days with precipitation. The variations in the increases may have been mainly caused by the changes in soil moisture content due to precipitation.

During the whole season, soil temperature was not positively correlated to $\mathrm{N}_{2} \mathrm{O}$ flux $(r=-0.084, p<0.01)$. Apparently soil temperature generally increased with time during the season, while the $\mathrm{N}_{2} \mathrm{O}$ flux did not. Therefore the $\mathrm{N}_{2} \mathrm{O}$ flux was correlated mainly with soil moisture (Fig. 10 and Table 4). Thus, compared to the factor of soil moisture, soil temperature had rather weak effects on $\mathrm{N}_{2} \mathrm{O}$ emissions at this specific site (Table 4).

However, when looking at the diurnal cycles, when soil moisture was not a predominant factor $\left(r_{\mathrm{sm}}<0.4, p>0.05\right.$ in the first and second sub-periods), soil temperature was significantly and positively correlated to $\mathrm{N}_{2} \mathrm{O}$ emissions $\left(r_{\mathrm{sm}} \geq\right.$ $0.56, p<0.001$ ) (Fig. 8). This indicates that, if soil moisture is not changed and other factors remain constant, the $\mathrm{N}_{2} \mathrm{O}$ emission during the daytime is higher than during the nighttime. The soil microorganisms were more active during the warmer daytime and produced more $\mathrm{N}_{2} \mathrm{O}$ emissions, as pointed out in Maljanen et al. (2002). However, the daytime fluxes were not always higher through the whole season, as shown on Fig. 7; i.e., the daytime fluxes were not higher during the third and the fourth periods because the soil moisture was a predominant factor $\left(r_{\mathrm{sm}}>0.4\right)$.

As expected, mineral nitrogen availability was an important factor in $\mathrm{N}_{2} \mathrm{O}$ emissions. The fertilizer applications before June may have caused higher soil $\mathrm{N}$ availabilities and higher $\mathrm{N}_{2} \mathrm{O}$ concentrations than after June (Fig. 6). The fertilizer amount of the second application was more than twice that of the first application; it most likely contributed to the dramatic increase in $\mathrm{N}_{2} \mathrm{O}$ concentration and flux after the second application (Fig. 5).

\subsection{Response of $\mathrm{N}_{2} \mathrm{O}$ emission to precipitation}

Soil moisture was strongly dependent on precipitation events. For most precipitation events during the experimental period, the sonic anemometer sensor heads were wet and could not measure the instantaneous wind velocities precisely. Consequently, estimates of the reaction time of emissions to precipitation are lacking. However, there were two events with low rainfall amounts $(<5 \mathrm{~mm}$ for each $30 \mathrm{~min}$ measurement period) when the sensor heads were not affected (the diagnostic record from the data logger showed the instruments functioned normally). During these events, the $\mathrm{N}_{2} \mathrm{O}$ emissions increased within $30 \mathrm{~min}$ after rainfall, indicating that soil $\mathrm{N}_{2} \mathrm{O}$ emission likely responds to rainfall and a change of soil moisture very quickly, as shown previously by Phillips et al. (2013) using dynamic chambers. Large emissions immediately after rain events have been shown in emission studies of other gases and vapors, such as Mercury (Bash 
and Miller, 2009; Gillis and Miller, 2000), and have been attributed to the evacuation of high concentration gas in soil pores as they fill up with water. The same mechanism may be occurring here. In any case, further examination is necessary because the spikes are large and significant emissions during active rainfall may be missed in this and most other field studies.

\subsection{Uncertainty in the gap-filling}

The gap-filling method used in this study may bring uncertainty to the total $\mathrm{N}_{2} \mathrm{O}$ flux estimating. However, it is a common practice that regression model is developed using "good" data (with $u^{*} \geq$ a threshold value); the regression model is then used to gap-fill the missing data and estimate the total value.

We evaluated the uncertainty of the regression equations used in the gap-fillings by comparing the regressed and the measured flux data when $\left(u^{*} \geq 0.2 \mathrm{~m} \mathrm{~s}^{-1}\right)$ and found the average error ratio was $14 \%$. The regression equations were from the "good" eddy covariance data $\left(u^{*} \geq 0.2 \mathrm{~m} \mathrm{~s}^{-1}\right)$. The "good" data may have been overestimated by about $12-16 \%$ (Table 2). Therefore the total $\mathrm{N}_{2} \mathrm{O}$ may be overestimated from the gap-filling by about 27 to $32 \%$ (e.g., $27 \%=(1+14 \%)(1+12 \%)-1)$.

Based on the equation in Fig. 11, the seasonally released $\mathrm{N}_{2} \mathrm{O}$ should be $3.76 \mathrm{~kg} \mathrm{~N}_{2} \mathrm{O}-\mathrm{N} \mathrm{ha}^{-1}$. However, in this study it was $6.87 \mathrm{~kg} \mathrm{~N}_{2} \mathrm{O}-\mathrm{Nha}^{-1}$. Therefore, the gap-filling and the EC measurement uncertainties may have partially contributed to the overestimated $\mathrm{N}_{2} \mathrm{O}$ release.

\section{Conclusions}

A new $\mathrm{N}_{2} \mathrm{O}$ analyzer (QCL spectrometer) was operated continuously for EC flux measurements of $\mathrm{N}_{2} \mathrm{O}$ in a cornfield in Nolensville, Tennessee during the period of 4 April-8 August 2012. Based on Allan variance analysis, the precision of the instrument was $0.066 \mathrm{ppbv}$ for $10 \mathrm{~Hz}$ measurements. The seasonal mean detection limit of the $\mathrm{N}_{2} \mathrm{O}$ flux measurements was $7.56 \mu \mathrm{g} \mathrm{N}_{2} \mathrm{O}-\mathrm{N} \mathrm{m}^{-2} \mathrm{~h}^{-1}$. The mean frequency loss ratio of the flux measurements was between 0.02 and 0.04 under the conditions of $0.4 \mathrm{~m} \mathrm{~s}^{-1}>u^{*} \geq 0.2 \mathrm{~m} \mathrm{~s}^{-1}$ during the day and 0.42 under the conditions of $0.3 \mathrm{~m} \mathrm{~s}^{-1}>u^{*} \geq$ $0.2 \mathrm{~m} \mathrm{~s}^{-1}$ during the night. We conclude that this $\mathrm{N}_{2} \mathrm{O}$ EC system can be used to provide reliable $\mathrm{N}_{2} \mathrm{O}$ flux measurements.

The cumulative $\mathrm{N}_{2} \mathrm{O}$ emission from the experimental site during the entire growing season was $6.87 \mathrm{~kg} \mathrm{~N}_{2} \mathrm{O}-\mathrm{N} \mathrm{ha}^{-1}$. This study showed that in addition to $\mathrm{N}$ availability in soil, the seasonal and diurnal $\mathrm{N}_{2} \mathrm{O}$ emission was highly dependent on soil moisture, and extremely high fluxes appeared after an $\mathrm{N}$ fertilization event combined with precipitation. Soil moisture variation was a dominant factor affecting $\mathrm{N}_{2} \mathrm{O}$ emissions compared to soil temperature.
Combining these results with nine previous studies in the literature allowed some preliminary synthesization. It appears that approximately $1.43 \%$ of each unit of $\mathrm{N}$ fertilizer was emitted to the atmosphere as $\mathrm{N}_{2} \mathrm{O}$.

\section{Future research}

We recommend that future studies focus on developing precision methods of minimizing $\mathrm{N}_{2} \mathrm{O}$ emissions by careful spatial and temporal control of fertilization amounts, water availability, and tilling practices. These should include "mechanism" studies quantifying the $\mathrm{N}_{2} \mathrm{O}$ flux rates from various interactions of water and $\mathrm{N}$ levels in soils. The effects of reducing the episodic nature of fertilization and water availability should be quantified and methods developed to make such reductions. Complete field-scale experiments designed to test application rates and application timing and yields will likely produce more usable results than even complete monitoring of commercial field operations.

Acknowledgements. The authors gratefully acknowledge financial support for this research from the USDA capacity building grant (2011-38821-30971) and Evans-Allen grant, as well as the support from the Illinois State Water Survey at the University of Illinois at Urbana-Champaign. The authors thank Roger Sauve (Tennessee State University) for helping arrange the commercial farm for the experiment. We also thank Eddie Williams, Daniel Doss, and Emeka Nwaneri for field experimental assistance. Opinions expressed are those of the authors and not necessarily those of the Illinois State Water Survey, the Prairie Research Institute, or the University of Illinois.

Edited by: A. B. Guenther

\section{References}

Arnold, K., Nilsson, M., Hanell, B., Weslien, P., and Klemedtsson, $\mathrm{L}$.: Fluxes of $\mathrm{CO}_{2}, \mathrm{CH}_{4}$ and $\mathrm{N}_{2} \mathrm{O}$ from drained organic soils in deciduous forests, Soil Biol. Biochem., 37, 1059-1071, 2005.

Aubinet, M., Grelle, A., Ibrom, A., Rannik, Ü., Moncrieff, J., Foken, T., Kowalski, A. S., Martin, P. H., Berbigier, P., Bernhofer, C., Clement, R., Elbers, J., Granier, A., Grünwald, T., Morgenstern, K., Pilegaard, K., Rebmann, C., Snijders, W., Valentini, R., and Vesala, T.: Estimates of the annual net carbon and water exchange of European forests: the EUROFLUX methodology, Adv. Ecol. Res., 30, 113-173, 2000.

Barr, A. G., Richardson, A. D., Hollinger, D. Y., Papale, D., Arain, M. A., Black, T. A., Bohrer, G., Dragoni, D., Fischer, M. L., Gu, L., Law, B. E., Margolis, H. A., McCaughey, J. H., Munger, J. W., Oechel, W., and Schaeffer, K.: Use of change-point detection for friction-velocity threshold evaluation in eddy-covariance studies, Agr. Forest Meteorol., 171-172, 3145, doi:10.1016/j.agrformet.2012.11.023, 2013, 2013. 
Bash, J. O. and Miller, D. R.: Growing season total gaseous mercury (TGM) flux measurements over an acer rubrum forest, Atmos. Environ., 43, 5953-5961, 2009.

Bouwman, A. F.: Direct emission of nitrous oxide from agricultural soils, Nutr. Cycl. Agroecosys., 46, 53-70, 1996.

Bouwman, A. F, Boumans, L., and Batjes, N. H.: Emissions of $\mathrm{N}_{2} \mathrm{O}$ and NO from fertilized fields: summary of available measurement data, Global Biogeochem. Cy., 16, 1-13, 2002.

Davidson, E. A.: Fluxes of nitrous oxide and nitric oxide from terrestrial ecosystems, in: Microbial production and consumption of greenhouse gases: methane, nitrogen oxides, and halomethanes, American Society for Microbiology, Washington, DC, 219-235, 1991

Davidson, E. A. and Swank, W. T.: Environmental parameters regulating gaseous nitrogen losses from two forested ecosystems via nitrification and denitrification, Appl. Environ. Microb., 52, 1287-1292, 1986.

Denmead, O. T.: Approaches to measuring fluxes of methane and nitrous oxide between landscapes and the atmosphere, Plant Soil, 309, 5-24, 2008.

Di Marco, C. D., Skiba, U., Weston, K., Hargreaves, K., and Fowler, D.: Field scale N2O flux measurements from grassland using eddy covariance, Water Air Soil Poll., 4, 143-149, 2004.

Dinsmore, K. J., Skiba, U. M., Billett, M. F., Rees, R. M., and Drewer, J.: Spatial and temporal variability in $\mathrm{CH}_{4}$ and $\mathrm{N}_{2} \mathrm{O}$ fluxes from a Scottish ombrotrophic peatland: implications for modelling and up-scaling, Soil Biol. Biochem., 6, 1315-1323, 2009.

Dobbie, K. E. and Smith, K. A.: Nitrous oxide emission factors for agricultural soils in Great Britain: the impact of soil water-filled pore space and other controlling variables, Glob. Change Biol., 9, 204-218, 2003.

Eddypro Version 3.0: Eddypro Version 3.0 User's Guide \&, LICOR, Inc., Lincoln, NE 68504-0425, 2012.

Edwards, G. C., Thurtell, G. W., Kidd, G. E., Dias, G. M., and Wagner-Riddle, C.: A diode laser based gas monitor suitable for measurement of trace gas exchange using micrometeorological technique, Agr. Forest Meteorol., 115, 71-89, 2003.

Eugster, W., Zeyer, K., Zeeman, M., Michna, P., Zingg, A., Buchmann, N., and Emmenegger, L.: Methodical study of nitrous oxide eddy covariance measurements using quantum cascade laser spectrometery over a Swiss forest, Biogeosciences, 4, 927-939, doi:10.5194/bg-4-927-2007, 2007.

Famulari, D., Nemitz, E., Marco, C. D., Phillips, G. J., Thomas, R., House, E., and Fowler, D.: Eddy-covariance measurements of nitrous oxide fluxes above a city, Agr. Forest Meteorol., 150, 786793, 2010.

Ferrara, R. M., Loubet, B., Tommasi, P. D., Bertolini, T., Magliulo, V., Cellier, P., Eugster, W., and Rana, G.: Eddy covariance measurement of ammonia fluxes: comparison of high frequency correction methodologies, Agr. Forest Meteorol., 158-159, 3042, 2012.

Forster, P., Ramaswamy, V., Artaxo, P., Berntsen, T., Betts, R., Fahey, D. W., Haywood, J., Lean, J., Lowe, D. C., Myhre, G., Nganga, J., Prinn, R., Raga, G., Schulz, M., and Van Dorland, R.: Changes in atmospheric constituents and in radiative forcing, in: Climate Change 2007: The Physical Science Basis. Contribution of Working Group I to the Fourth Assessment Report of the
Intergovernmental Panel on Climate Change, Cambridge University Press, Cambridge, Chapt. 2, 2007.

Gillis, A. A. and Miller, D. R.: Some local environmental effects on mercury emission and absorption at a soil surface, Sci. Total Environ., 260, 191-200, 2000.

Grant, R. F. and Pattey, E.: Modelling variability in $\mathrm{N}_{2} \mathrm{O}$ emissions from fertilized agricultural fields, Soil Biol. Biochem., 35, 225243, 2003.

Gu, L., Falge, E. M., Boden, T., Baldocchi, D. D., and Black, T. A.: Objective threshold determination for nighttime eddy flux filtering, Agr. Forest Meteorol., 128, 179-197, 2005.

Halvorson, A. D., Schweissing, F. C., Bartolo, M. E., and Reule, C. A.: Corn response to nitrogen fertilization in a soil with high residual nitrogen, Agron. J., 97, 1222-1229, 2005.

Horst, T. W. and Lenschow, D. H.: Attenuation of scalar fluxes measured with spatially-displaced sensors, Bound.-Lay. Meteorol., 130, 275-300, 2009.

Ibrom, A., Dellwik, E., Larse, S. E., and Pilegaard, K.: On the use of the Webb-Pearman-Leuning theory for closed-path eddy correlation measurements, Tellus B, 59, 937-946, 2007.

Jones, S. K., Famulari, D., Di Marco, C. F., Nemitz, E., Skiba, U. M., Rees, R. M., and Sutton, M. A.: Nitrous oxide emissions from managed grassland: a comparison of eddy covariance and static chamber measurements, Atmos. Meas. Tech., 4, 2179-2194, doi:10.5194/amt-4-2179-2011, 2011.

Jungkunst, H. F., Fless, H., Scherber, C., and Fiedler, S.: Groundwater level controls $\mathrm{CO}_{2}, \mathrm{~N}_{2} \mathrm{O}$ and $\mathrm{CH}_{4}$ fluxes of three different hydromorphic soil types of a temperate forest ecosystem, Soil Biol. Biochem., 40, 2047-2057, 2008.

Kaimal, J. C. and Finnigan, J. J.: Atmospheric Boundary Layer Flows, 2nd edn., Oxford University Press, New York, 1994.

Kaimal, J. C., Wyngaard, J. C., Izumi, Y., and Cote, O. R.: Deriving power spectra from a three-component sonic anemometer, J. Appl. Meteorol., 7, 827-837, 1972.

Kitzler, B., Zechmeister-Boltenstern, S., Holtermann, C., Skiba, U., and Butterbach-Bahl, K.: Controls over $\mathrm{N}_{2} \mathrm{O}, \mathrm{NO}_{\mathrm{x}}$ and $\mathrm{CO}_{2}$ fluxes in a calcareous mountain forest soil, Biogeosciences, 3 , 383-395, doi:10.5194/bg-3-383-2006, 2006.

Klemedtsson, L., Klemedtsson, A. K., Moldan, F., and Weslien, P.: Nitrous oxide emission from Swedish forest soils in relation to liming and simulated increased N-deposition, Biol. Fert. Soils, 25, 290-295, 1996.

Kroeze, C., Mosier, A., and Bouwman, L.: Closing the global warming budget: a retrospective analysis 1500-1994, Global Biogeochem. Cy., 13, 1-8, 1999.

Kroon, P. S., Hensen, A., Jonker, H. J. J., Zahniser, M. S., van't Veen, W. H., and Vermeulen, A. T.: Suitability of quantum cascade laser spectroscopy for $\mathrm{CH}_{4}$ and $\mathrm{N}_{2} \mathrm{O}$ eddy covariance flux measurements, Biogeosciences, 4, 715-728, doi:10.5194/bg-4715-2007, 2007.

Laville, P., Jambert, C., Cellier, P., and Delmas, R.: Nitrous oxide fluxes from a fertilized maize crop using micrometeorological and chamber methods, Agr. Forest Meteorol., 96, 19-38, 1999.

Lee, J., Hopmans, J. W., Kessel., C., King, A. P., Evatt., K. J., Louie, D., Rolston, D. E., and Six, J.: Tillage and seasonal emissions of $\mathrm{CO}_{2}, \mathrm{~N}_{2} \mathrm{O}$ and $\mathrm{NO}$ across a seed bed and at the field scale in a Mediterranean climate, Agr. Ecosyst. Environ., 129, 378-390, 2009. 
Li, J., Tong, X., Yu, Q., Dong, Y., and Peng, C.: Micrometeorological measurements of nitrous oxide exchange in a cropland, Atmos. Environ., 42, 6992-7001, 2008.

Liu, C., Wang, K., and Zheng, X.: Responses of $\mathrm{N}_{2} \mathrm{O}$ and $\mathrm{CH}_{4}$ fluxes to fertilizer nitrogen addition rates in an irrigated wheatmaize cropping system in northern China, Biogeosciences, 9, 839-850, doi:10.5194/bg-9-839-2012, 2012.

Luo, G. J., Kiese, R., Wolf, B., and Butterbach-Bahl, K.: Effects of soil temperature and moisture on methane uptake and nitrous oxide emissions across three different ecosystem types, Biogeosciences, 10, 3205-3219, doi:10.5194/bg-10-3205-2013, 2013.

Ma, B. L., Wu, T. Y., Tremblay, N., Deen, W., Morrison, M. J., Mclaughlin, N. B., Gregorich, E. G., and Stewart, G.: Nitrous oxide fluxes from corn fields: on-farm assessment of the amount and timing of nitrogen fertilizer, Glob. Change Biol., 16, 156$170,2010$.

Maljanen, M., Martikainen, P. J., Aaltonen, H., and Silvola, J.: Short-term variation in fluxes of carbon dioxide, nitrous oxide and methane in cultivated and forested organic boreal soils, Soil Biol. Biochem., 34, 577-584, 2002.

Mammarella, I.: Lecture 1 EC Method Background and Theory, available at: http://www.abba.ethz.ch/committee/LECTURE_ Mammarella.pdf (last access: 31 July 2014), ETH Zurich, Zurich, Switzerland, 2011.

Mammarella, I., Werle, P., Pihlatie, M., Eugster, W., Haapanala, S., Kiese, R., Markkanen, T., Rannik, Ü., and Vesala, T.: A case study of eddy covariance flux of $\mathrm{N}_{2} \mathrm{O}$ measured within forest ecosystems: quality control and flux error analysis, Biogeosciences, 7, 427-440, doi:10.5194/bg-7-427-2010, 2010.

Molodovskaya, M., Warland, J., Richards, B. K., Oberg, G., and Steenhuis, T. S.: Nitrous oxide from heterogeneous agricultural landscapes: source contribution analysis by eddy covariance and chambers, Soil Sci. Soc. Am. J., 75, 1829-1838, 2011.

Moncrieff, J., Clement, R., Finnigan, J., and Meyers, T.: Averaging, Detrending, and Filtering of Eddy Covariance Time Series, Vol. 29, Chapt. 2, Kluwer Academic Publishers, Dordrecht, Netherlands, 7-31, 2004.

Mosier, A., C., Kroeze, Nevison, C., Oenema, O., Seitzinger, S., and Cleemput, O.: Closing the global $\mathrm{N}_{2} \mathrm{O}$ budget: nitrous oxide emissions through the agricultural nitrogen cycleOECD/IPCC/IEA phase II development of IPCC guidelines for national greenhouse gas inventory methodology, Nutr. Cycl. Agroecosys., 52, 225-248, 1998.

Neftel, A., Flechard, C. R., Ammann, C., Conen, F., Emmenegger, L., and Zeyer, K.: Experimental assessment of $\mathrm{N}_{2} \mathrm{O}$ background fluxes in grassland systems, Tellus B, 59, 470-482, 2007.

Neftel, A., Ammann, C., Fischer, C., Spirig, C., Conen, F., Emmenegger, L., Tuzson, B., and Wahlen, S.: $\mathrm{N}_{2} \mathrm{O}$ exchange over managed grassland: application of a quantum cascade laser spectrometer for micrometeorological flux measurements, Agr. Forest Meteorol., 150, 775-785, 2010.

Nelson, D.: TDLWintel User's Manual,Aerodyne Research, Inc, Billerica, MA, USA, 2002.

Nelson, D. D., McManus, B., Urbanski, S., Herndon, S., and Zahniser, M. S.: High precision measurements of atmospheric nitrous oxide and methane using thermoelectrically cooled midinfrared quantum cascade lasers and detectors, Spectrochim. Acta A, 60, 3325-3335, 2004.
Papale, D., Reichstein, M., Aubinet, M., Canfora, E., Bernhofer, C., Kutsch, W., Longdoz, B., Rambal, S., Valentini, R., Vesala, T., and Yakir, D.: Towards a standardized processing of Net Ecosystem Exchange measured with eddy covariance technique: algorithms and uncertainty estimation, Biogeosciences, 3, 571-583, doi:10.5194/bg-3-571-2006, 2006.

Phillips, R. L., Tanaka, D. L., Archer, D. W., and Hanson, J. D.: Fertilizer application timing influences greenhouse gas fluxes over a growing season, J. Environ. Qual., 28, 1569-1579, 2009.

Phillips, R., Griffith, D. W. T., Dijkstra, F.,Lugg, G., Lawrie, R., and Macdonald, B.: Tracking short-term effects of $15 \mathrm{~N}$ addition on $\mathrm{N}_{2} \mathrm{O}$ fluxes using FTIR spectroscopy. J. Environ. Qual. 42, 1327-1340, 2013.

Pihlatie, M., Rinne, J., Ambus, P., Pilegaard, K., Dorsey, J. R., Rannik, Ü., Markkanen, T., Launiainen, S., and Vesala, T.: Nitrous oxide emissions from a beech forest floor measured by eddy covariance and soil enclosure techniques, Biogeosciences, 2, $377-$ 387, doi:10.5194/bg-2-377-2005, 2005.

Ravishankara, A. R., Daniel, J. S., and Portmann, R. W.: Nitrous oxide $\left(\mathrm{N}_{2} \mathrm{O}\right)$ : the dominant ozone-depleting substance emitted in the 21 st century, Science, 326, 123-125, 2009.

Saleska, S. R., Miller, S. D., Matross, D. M., Goulden, M. L.,Wofsy, S. C., da Rocha, H. R., de Camargo, P. B., Crill, P., Daube, B. C., de Freitas, H. C., Hutyra, L., Keller, M., Kirchhoff, V., Menton, M., Munger, J. W., Pyle, E. H., Rice, A. H., and Silva, H.: Carbon in Amazon forests: unexpected seasonal fluxes and disturbanceinduced losses, Science, 302, 1554-1557, 2003.

Schindlbacher, A., Zechmeister-Boltenstern, S., and ButterbachBahl, K.: Effects of soil moisture and temperature on $\mathrm{NO}, \mathrm{NO}_{2}$, and $\mathrm{N}_{2} \mathrm{O}$ emissions from European forest soils, J. Geophys. Res., 109, D17302, doi:10.1029/2004JD004590, 2004.

Simpson, I. J., Edwards, G. C., Thurtell, G. W., den Hartog, G., Neumann, H. H., and Staebler, R. M.: Micrometeorological measurements of methane and nitrous oxide exchange above a boreal aspen forest, J. Geophys. Res., 102, 29331-29341, 1997.

Smith, K. A., Ball, T., Conen, F., Dobbie, K. E., Massheder, J., and Rey, A.: Exchange of greenhouse gases between soil and atmosphere: interactions of soil physical factors and biological processes, Eur. J. Soil Sci., 54, 779-791, 2003.

Stull, R. B.: An Introduction to Boundary Layer Meteorology, Kluwer Academic Publishers, Dordrecht, 1988.

Tao, L., Sun, K., Buglione, J., and Zondlo, M.: Flux chamber measurements of nitrous oxide emission at Wetlands, available at: http://meri.njmeadowlands.gov/projects/ flux-chamber-measurements-of-nitrous-oxide-emission-at-wetlands/ (last access: 31 July 2014), Meadowlands Environmental Research Institute, Lyndhurst, New Jersey, 2013.

Ussiri, D. A. N., Lal, R., and Jarecki, M. K.: Nitrous oxide and methane emissions from long-term tillage under a continuous corn cropping system in Ohio, Soil Till. Res., 104, 247-255, 2009.

Vickers, D. and Mahrt, L.: Quality control and flux sampling problems for tower and aircraft data, J. Atmos Ocean. Tech., 14, 512526, 1997.

Wagner-Riddle, C., Furon, A., McLaughlin, N. L., Lee, I., Barbeau, J., Jayasundara, S., Parkin, G., Von Bertoldi, P., and Warland, J.: Intensive measurement of nitrous oxide emissions from a cornsoybean-wheat rotation under two contrasting management systems over 5 years, Glob. Change Biol., 8, 1722-1736, 2007. 
Wang, K, Zheng, X., Pihlatie, M., Vesala, T., Liu, C., Haapanala, S., Mammarella, I., Rannik, Ü., and Liu, H.: Comparison between static chamber and tunable diode laser-based eddy covariance techniques for measuring nitrous oxide fluxes from a cotton field, Agr. Forest Meteorol., 171-172, 9-19, 2013.

Wienhold, F. G., Welling, M., and Harris, G. W.: Micrometeorological measurements and source region analysis of nitrous oxide fluxes from an agricultural soil, Atmos. Environ., 29, 2219-2227, 1995.
Zona, D., Janssens, I. A., Verlinden, M. S., Broeckx, L. S., Cools, J., Gioli, B., Zaldei, A., and Ceulemans, R.: Impact of extreme precipitation and water table change on $\mathrm{N}_{2} \mathrm{O}$ fluxes in a bioenergy poplar plantation, Biogeosciences Discuss., 8, 2057 2092, doi:10.5194/bgd-8-2057-2011, 2011.

Zou, J, Huang, Y., Lu, Y., Zheng, X., and Wang, Y.: Direct emission factor for $\mathrm{N}_{2} \mathrm{O}$ from rice-winter wheat rotation systems in southeast China, Atmos. Environ., 39, 4755-4765, 2005. 